ORNL/TM-5812

Distribution

Category UC-25

Contract No. W-7405-eng-26

METALS AND CERAMICS DIVISION

\title{
THE EFFECTS OF HELIUM IMPURITIES ON SUPERALLOYS
}

J. E. Selle

Date Published: July 1977

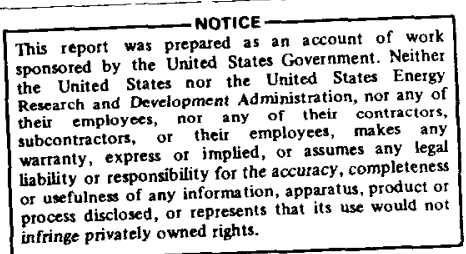

OAK RIDGE NATIONAL LABORATORY

Oak Ridge, Tennessee $\mathbf{3 7 8 3 0}$

operated by

UNION CARBIDE CORPORATION

for the

\section{ENERGY RESEARCH AND DEVELOPMENT ADMINISTRATION}

This dorument is

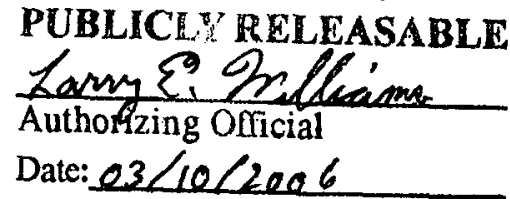




\section{DISCLAIMER}

This report was prepared as an account of work sponsored by an agency of the United States Government. Neither the United States Government nor any agency Thereof, nor any of their employees, makes any warranty, express or implied, or assumes any legal liability or responsibility for the accuracy, completeness, or usefulness of any information, apparatus, product, or process disclosed, or represents that its use would not infringe privately owned rights. Reference herein to any specific commercial product, process, or service by trade name, trademark, manufacturer, or otherwise does not necessarily constitute or imply its endorsement, recommendation, or favoring by the United States Government or any agency thereof. The views and opinions of authors expressed herein do not necessarily state or reflect those of the United States Government or any agency thereof. 


\section{DISCLAIMER}

Portions of this document may be illegible in electronic image products. Images are produced from the best available original document. 


\section{CONTENTS}

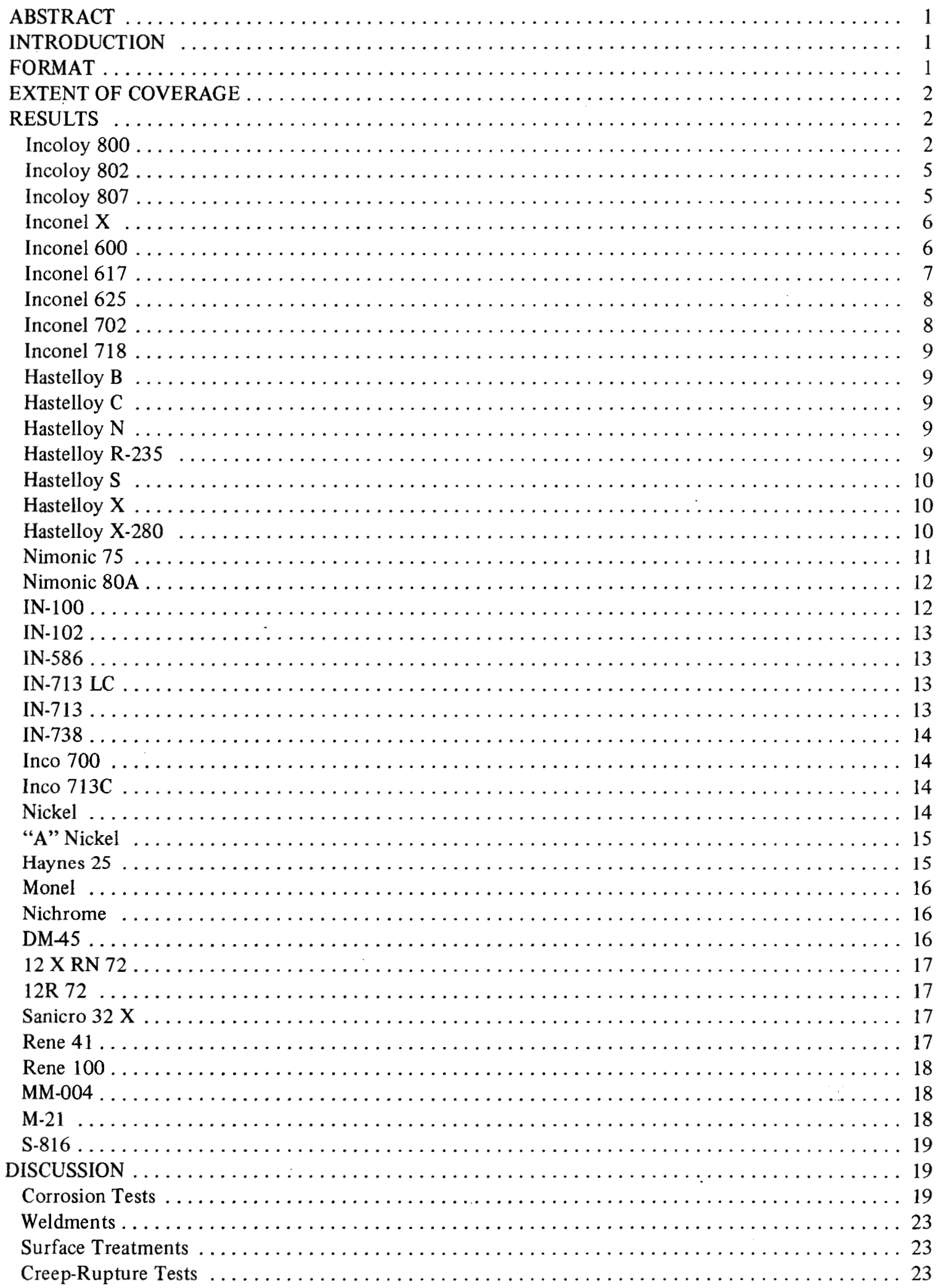




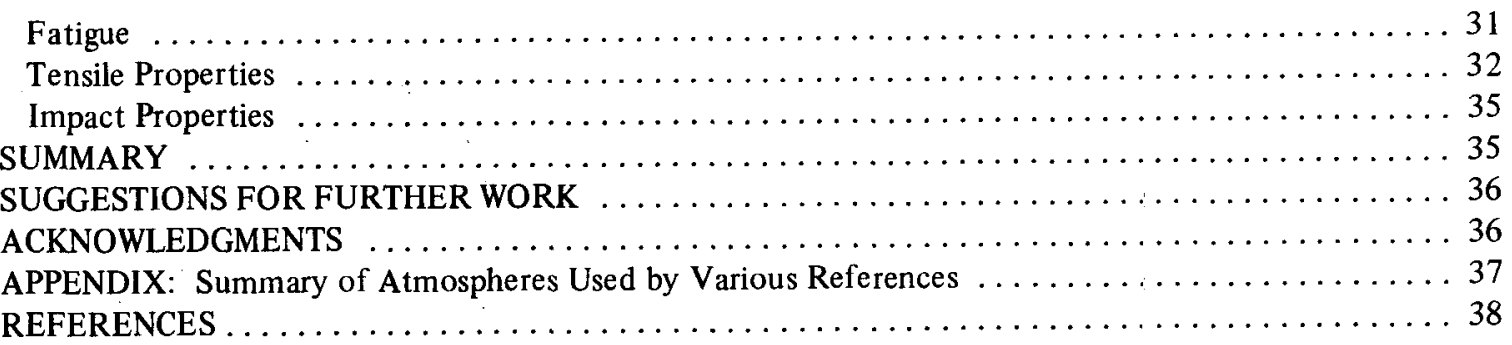




\title{
THE EFFECTS OF HELIUM IMPURITIES ON SUPERALLOYS
}

\author{
J. E. Selle
}

\begin{abstract}
A review of the literature on the effects of helium impurities on superalloys at elevated temperatures was undertaken. The actual effects of these impurities vary depending on the alloy, composition of the gas atmosphere, and temperature. In general, exposure in helium produces significant but not catastrophic changes in the structure and properties of the alloys. The effects of these treatments on the structure, creep, fatigue, and mechanical properties of the various alloys are reviewed and discussed. Suggestions for future work are presented.
\end{abstract}

\section{INTRODUCTION}

The Brayton Isotope Power System (BIPS) program proposes to use a xenon-helium gas mixture as a working fluid in a Brayton Cycle system. In this concept, the working fluid is heated by a radioisotopic heat source and is used in a closed-cycle gas turbine engine to generate electrical energy at a net efficiency in excess of $25 \% .^{1}$ Xenon and helium, being inert gases, should have no effect on the properties of materials with which they come in contact. However, impurities in the gases and offgassing impurities from the system walls have been found in some cases to alter considerably the mechanical properties of certain alloys.

In view of this potential problem, it is the purpose of this report to summarize available literature on the effects of helium and its impurities on the structure and properties of superalloys. Superalloys are of interest here because of their potential use in the BIPS program. Information available through August 1976 has been used. Since it was impossible in most cases to critically examine the test specimens and test systems used in the studies surveyed, it was necessary to rely primarily on the individual investigators' technical judgment. An attempt will be made to rationalize the effects on the various properties of superalloys in terms of specific mechanisms.

\section{FORMAT}

During the analysis of the available literature, difficulties were encountered in comparing data from the various sources. In some cases conflicting results were reported by different workers. These difficulties are no doubt caused by variations in test conditions. Some of the variables involved are:

1. helium purity and impurity species,

2. temperature of test,

3. time of test,

4. flow rate of gas,

5. method of analysis,

6. differences in material chemistry and prior heat treatment. 
In many cases it was difficult to determine whether there was any effect of helium treatment on the material, since no comparisons were made with air data taken on the same heat of material. Therefore, in these instances no statement of relative effects can be made.

It is proposed in this report to discuss the results available on each alloy in turn. Each individual section of the report will include the results of corrosion tests and metallographic analyses, a brief qualitative discussion of any studies of mechanical properties, a more detailed discussion and quantitative data on mechanical properties, and finally a discussion of this information in terms of mechanisms and their effects on materials.

\section{EXTENT OF COVERAGE}

A summary of the alloys considered in this report is given in Table 1. Also included in this table are the nominal compositions of each alloy. To obtain the actual compositions used in each test, the reader is referred to the references indicated.

A summary of the extent of information available on mechanical property data is given in Table 2. This table summarizes the type of mechanical property data available for each alloy and the number of references offering data on each respective property.

Atmospheres covered in this report encompass a wide range of purity and contaminating species. Many tests used Grade $\mathrm{A}$ helium with a nominal composition of $99.8 \%$ helium and impurities of $\mathrm{N}_{2}$ and $\mathrm{O}_{2}$. Others attempted to use ultrapure helium with less than $1 \mathrm{ppm}$ total impuitities. Still other workers attempted to simulate the gases expected in the various gas-cooled reactors. All, of these atmospheres are summarized in Table $3 .^{2-6}$

Other workers studied the effects of impurities at relatively high partial pressures (up to 100 torr) in varying ratios. Some of these studies were conducted using no helium but only the pure reacting gases. Such studies are included in this report because they consider the effects of these reactants regardless of their partial pressure. Since the thermodynamics of most reactions do not change significantly with total pressure, this is not cause for concern.

Since the concept of helium. atmosphere has many meanings, the analysis of the results available has been complicated and sometimes leads to conflicts. A summary of the atmospheres used in the various references is given in Appendix $\mathbf{A}$.

\section{RESULTS}

\section{Incoloy 800}

\section{Corrosion tests}

Impurities in the helium, such as $\mathrm{H}_{2} \mathrm{O}$ and $\mathrm{O}_{2}$, result in the formation of a thin oxide film on the surface. $^{3,6-12}$ That the oxide layer is at least partially protective is indicated by the fact that several investigators have noted that the rate of attack progressively decreases with time. ${ }^{6,8,13}$ In many cases intergranular attack and internal oxidation were also observed..$^{3,6-8,10-12}$ Bates et al ${ }^{10}$ identified the intergranular product as primarily made up of oxides of aluminum and titaniuni. In the unstrained condition aluminum, titanium, and some silicon were found in the intergranular oxide; under strained conditions chromium and manganese were also found. This indicates that periodic cracking and reoxidation of the grain boundaries occurs during creep.

Kondo, Kikuyama, and Shindo ${ }^{12}$ showed that higher corrosion rates were largely dependent on the existence of titanium in the alloy. A titanium-free heat of Incoloy 800 exhibited much less weight gain than 
Table 1. Nominal composition of alloys (percent)

\begin{tabular}{|c|c|c|c|c|c|c|c|c|c|c|c|c|c|c|c|}
\hline Alloy & c & Mn & $\mathrm{Si}$ & $\mathrm{Cr}$ & $\mathrm{Ni}$ & $C_{0}$ & Mo & w & $\mathrm{Nb}$ & $\mathrm{Ti}$ & $\mathrm{Al}$ & B & $\mathrm{Z}_{\mathrm{r}}$ & $\mathrm{Fe}$ & Other \\
\hline Incoloy 800 & 0.05 & 0.75 & 0.50 & 21 & 32.5 & & & & & 0.38 & 0.38 & & & Balance & \\
\hline 802 & 0.35 & 0.75 & 0.38 & 21 & .32 .5 & & & & & & & & & Balunce & $0.38 \mathrm{cu}$ \\
\hline $807^{a}$ & 0.07 & 0.83 & 0.69 & 20.34 & 40.75 & 7.58 & 0.24 & & & 0.37 & 0.47 & $1.4 \mathrm{ppm}$ & & Batlance & \\
\hline Inconcl $X$ & 0.04 & 0.70 & 0.30 & 15 & Balance & & & & 1 & 2.5 & 0.9 & & & 7 & \\
\hline & 0.08 & 0.50 & 0.25 & 15.5 & Balance & & & & & & & & & 8 & \\
\hline 617 & 0.07 & & & 22.0 & Balance & 12.5 & 9.0 & & & & 0 & & & & \\
\hline 625 & 0.05 & 0.25 & 0.25 & 21.5 & Bulance & & 9.0 & & 3.65 & 0.2 & 0.2 & & & 2.5 & \\
\hline 702 & 0.05 & 0.50 & 0.35 & 15.5 & Balance & & & & & 0.63 & 3.25 & & & 1.0 & $0.05 \mathrm{~S} .0 .25 \mathrm{Cu}$ \\
\hline & 0.04 & 0.18 & 0.18 & 19.0 & Ballance & & 3.1 & & 5.0 & 0.9 & 0.5 & & & 18.5 & \\
\hline Hastetloy B & $\therefore 0.05 *$ & $1.0^{*}$ & $1.0^{*}$ & $1.0^{*}$ & Balance & $2.5^{*}$ & 28.0 & & & & & & & 5.0 & \\
\hline c & $0.08^{*}$ & $i .0^{*}$ & $1.0^{*}$ & 15.5 & Balance & $2.5 *$ & 16.0 & 3.8 & & & & & & 5.5 & \\
\hline $\mathrm{N}$ & $0.08^{*}$ & $0.8^{*}$ & $1.0^{*}$ & $\begin{array}{r}7.0 \\
.55\end{array}$ & Batance & $0.2^{*}$ & 16.5 & $0.5^{*}$ & & & & $0.01^{*}$ & & $5.0^{*}$ & $0.5(\mathrm{~A})+\mathrm{Ti})$ \\
\hline R.235 & 0.15 & & & 15.5 & Bulance & $2.5^{*}$ & 5.5 & & & 2.5 & 2.0 & & & 10.0 & \\
\hline $\mathrm{S}$ & $0.02 *$ & 0.50 & 0.40 & 15.5 & Balance & & 14.5 & & & & 0.2 & 0.009 & & 1.0 & $0.02 \mathrm{Lu}$ \\
\hline $\begin{array}{c}X \\
X-280^{b}\end{array}$ & & $\begin{array}{l}1.0^{*} \\
0.75\end{array}$ & $\begin{array}{l}1.0^{*} \\
0.53\end{array}$ & $\begin{array}{l}21.8 \\
21.73\end{array}$ & $\begin{array}{l}\text { Balance } \\
\text { Balance }\end{array}$ & $\begin{array}{l}2.5^{*} \\
0.11\end{array}$ & $\begin{array}{l}9.0 \\
8.65\end{array}$ & $\begin{array}{l}0.6 \\
0.38\end{array}$ & & & & & & $\begin{array}{l}18.5 \\
18.66\end{array}$ & \\
\hline Nimonic $75^{\circ}$ & 0.12 & i. $0^{*}$ & $1.0^{*}$ & 20 & Bulance & & & & & 0.40 & & & & $5^{*}$ & \\
\hline $80 \mathrm{~A}$ & & $1^{*}$ & $1^{*}$ & & Balance & $2^{*}$ & & & & 2.25 & 1.25 & & & $5^{*}$ & \\
\hline PE-13 & $0.05-0.1$ & & & $20.5-23.0$ & Bulance & $0.5-2.5$ & $8-10$ & $0.2-1.0$ & & & & & & $17-20$ & \\
\hline $1 \mathrm{~N}-100$ & 0.16 & 0.85 & 0.25 & 0.6 & 1.2 & & 0.55 & & & & & & & Baliance & $0.07 \mathrm{~V}, 0.25 \mathrm{Cu} .0 .06 \mathrm{~N}$ \\
\hline & 0.06 & $0.75^{*}$ & $0.4^{*}$ & 15.0 & Bulance & & 2.9 & 3.0 & 2.9 & 0.5 & 0.5 & 0.005 & 0.03 & 7.0 & $0.02 \mathrm{Mg}$ \\
\hline & 0.005 & & & 25.0 & Balance & & 10.0 & & & & & & & & $0.015 \mathrm{Mg}, 0.03 \mathrm{Ce}$ \\
\hline & 0.13 & $<0.02$ & $<0.05$ & 13.6 & Baliance & 0.18 & 4.35 & $<0.10$ & $<2.12$ & 0.85 & 6.00 & 0.009 & 0.07 & 0.14 & \\
\hline $713 \mathrm{LCC}$ & 0.05 & 0.01 & $<0.01$ & 12.1 & Balance & 0.15 & 4.5 & & 2.0 & 0.74 & 6.30 & 0.01 & 0.10 & 0.07 & \\
\hline 738 & 0.17 & & & 16 & Bulance & 8.5 & 1.75 & 2.6 & 0.9 & 3.4 & 3.4 & 0.01 & 0.10 & & $1.75 \mathrm{Ta}$ \\
\hline Inco 700 & 0.10 & 2 & & 15 & Balunce & 29 & 3 & & & 2.2 & 3 & & & 4 & \\
\hline $713 \mathrm{C}$ & 0.14 & & & 13 & Balance & $1^{*}$ & 4.5 & & 2 & 0.7 & 6 & 0.01 & & $2.5^{*}$ & \\
\hline Haynes 25 & 0.10 & 1.50 & 0.50 & 20 & 10 & Bulance & & 15 & & & & & & & \\
\hline Nickel & & & & & 99.8 & & & & & & & & & & \\
\hline TD Nickel & & & & & 98 & & & & & & & & & & $2.0 \mathrm{ThO}_{2}$ \\
\hline "A" Nickel & 0.1 & 0.2 & 0.05 & & 99.4 & & & & & & & & & 0.15 & $0.1 \mathrm{Cu}, 0.00 \mathrm{~s}$ \\
\hline \multicolumn{16}{|l|}{ Nichrome } \\
\hline Monel & $0.3^{*}$ & $2.0^{*}$ & $0.50^{*}$ & $63-70$ & & & & & & & & & & $2.50^{*}$ & 0.024 S. Bal. Cu \\
\hline DM-45 & 0.45 & 0.55 & 0.65 & 1.25 & & & 0.50 & & & & & & & Balance & \\
\hline $12 \mathrm{R} 72$ & 0.09 & 1.89 & 0.45 & 15.0 & 15.0 & & 1.47 & & & 0.48 & & 0.006 & & & \\
\hline $12 \times \mathrm{RN} 72^{\mathrm{C}}$ & 0.1 & 1.80 & 0.17 & 18.9 & 24.6 & & 1.47 & & & 0.48 & & 0.006 & & & $0.025 \mathrm{~N}$ \\
\hline Sanicro $32 \mathrm{X}$ & 0.07 & .0 .55 & 0.55 & 21 & 31 & & & 3.0 & & 0.35 & 0.35 & & & Balance & \\
\hline Rene 41 & 0.09 & & & 19 & Balance & 11 & 10 & & & 3.1 & 1.5 & $0.01 *$ & & & \\
\hline Renc 100 & 0.2 & & & $9-10$ & Balance & $14-16$ & $2.7-3.3$ & & & $4.0-4.4$ & $5.3-5.7$ & 0.02 & $0.03-0.09$ & $1.0^{*}$ & $1.0 \mathrm{v}$ \\
\hline $\mathrm{N}-155$ & 0.15 & 1.5 & 0.5 & 21 & 20 & 20 & 3.0 & 2.5 & 1.0 & & & & & Balance & $0.15 \mathrm{~N}$ \\
\hline S-816 & 0.38 & 1.20 & 0.40 & 20 & 20 & Balance & 4.0 & 40 & 4.0 & & & & & 4.0 & \\
\hline MM004 ${ }^{d}$ & 0.056 & $<0.02$ & $<0.05$ & 11.9 & Ballance & 0.18 & 4.37 & $<0.10$ & 1.72 & 0.70 & 5.60 & 0.015 & 0.10 & 0.45 & $1.27 \mathrm{H} \mathrm{F}$ \\
\hline $\mathbf{M} 21^{d}$ & 0.110 & $<0.02$ & $<0.05$ & 5.3 & Balance & $<0.10$ & 1.83 & 8.00 & 1.43 & $<0.10$ & 6.25 & & 0.10 & 0.20 & \\
\hline
\end{tabular}

$*=$ maximum.

${ }^{a}$ Exact compusition, tuken irum ref. 12.

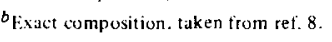

"F.xact composition, tuken from ref. 9.

${ }^{d}$ Exact compusition, taken from ret. 2.

${ }^{C}$ Alliy desiznation or composition not given.

$f_{\text {l:xact composition, taken from ref. } 10 .}$ 
Table 2. References providing mechanical property data for alloys

\begin{tabular}{|c|c|c|c|c|}
\hline Alloy & Creep & Fatigue & Tensile & Impact \\
\hline Incoloy 800 & refs. 4,10 & ref. 12 & & \\
\hline Incoloy 802 & 9 & & & \\
\hline Inconel $\mathrm{X}$ & 18,19 & 18 & 11 & \\
\hline Inconel 600 & 9 & & & \\
\hline Inconel 617 & $2,5,9,21$ & & 2 & 2 \\
\hline Inconel 625 & 5,9 & & & \\
\hline Hastelloy C & 22 & & & \\
\hline Hastelloy X & $5,9,16,27,36,37$ & & 11 & \\
\hline Nimonic 75 & & & 29 & \\
\hline IN -100 & 2 & & 2 & 2 \\
\hline IN-102 & 9 & & & \\
\hline IN-713 & 2 & & 2 & 2 \\
\hline IN-738 & 2 & & 2 & \\
\hline Inco-700 & 18 & 18 & & \\
\hline Inco-713C & 18 & 18 & & \\
\hline Nickel & 30,31 & 32 & & \\
\hline DM -45 & 19 & & & \\
\hline $12 \mathrm{XRN} 72$ & 9 & & & \\
\hline $12 \mathrm{R} 72$ & 10 & & & \\
\hline Sanicro $32 \mathrm{X}$ & 9 & & & \\
\hline Rene 41 & & & 11 & \\
\hline Rene 100 & 2 & & 2 & \\
\hline MM 004 & & & 2 & \\
\hline M-21 & 2 & & 2 & 2 \\
\hline S-816 & 19 & & & \\
\hline
\end{tabular}

did the normal alloy at $1000^{\circ} \mathrm{C}$. Similarly, Dixmier et al. ${ }^{14}$ found that the degree of intergranular attack increased with increases in the titanium and aluminum concentration.

After testing eight alloys for $600 \mathrm{hr}$ at $1000^{\circ} \mathrm{C}$, Sakikibara, Banno, and Siekino ${ }^{15}$ reported the least chromium depletion in Incoloy 800 . However, all the alloys oxidized more in helium than in air.

\section{Creep}

The results of creep tests are inconsistent. Wood, Farrow, and Burke ${ }^{4}$ found that rupture times were shorter in helium than in air; while Bates et al. ${ }^{10}$ found the creep-rupture life in helium as good as or superior to that in air. Wood, Farrow, and Burke also found that helium had no effect on rupture ductility, and they found that creep rates in helium are higher than in air. On the other hand, Bates et al. found that creep ductility was lower in helium than in air. They did not discuss creep rate, but their data indicates that 
Table 3. Coolant gases expected in various gas-cooled reactors ${ }^{a}$

\begin{tabular}{|c|c|c|c|}
\hline \multirow[b]{2}{*}{$\overline{\text { Species }}$} & \multicolumn{3}{|c|}{ Composition $\left[\mu \mathrm{atm}^{b}\right]$} \\
\hline & Peach Bottom & Dragon & $\overline{A V R}$ \\
\hline $\mathrm{H}_{2} \mathrm{O}$ & 0.02 & 1 & $<1$ \\
\hline $\mathrm{CO}_{2}$ & $<1$ & $<0.4$ & $50-150$ \\
\hline $\mathrm{H}_{2}$ & 230 & 20 & $50-150$ \\
\hline $\mathrm{CO}$ & 10 & 12 & $200-500$ \\
\hline $\mathrm{CH}_{4}$ & 23 & 3 & $<2-10$ \\
\hline $\mathrm{N}_{2}$ & $10-20$ & 3 & $<5-50$ \\
\hline $\mathrm{O}_{2}$ & $<1$ & $<0.4$ & \\
\hline
\end{tabular}

$a_{\text {From }}$ S. N. Rosenwasser and W. R. Johnson, Gas-Turbine HTGR Materials Screening Test Program Interim Results, GA-A 13931, General Atomic Company, San Diego, Calif. (June 30, 1976).

$b_{\mu \mathrm{atm}}=$ volume ppm $\times$ helium pressure at 23,20 , and 10 atm for Peach Bottom, Dragon, and AVR respectively.

the creep rate in helium would be lower than in air. Wolwowicz ${ }^{16}$ found that creep-rupture properties in 1500:500:50:50 ppm $\mathrm{H}_{2}: \mathrm{CO}: \mathrm{CH}_{4}: \mathrm{H}_{2} \mathrm{O}$ compare favorably with published air data for other heats. Slightly longer creep-rupture lives and slightly lower creep rates were found by Wolwowicz; this is in general agreement with Bates et al. ${ }^{10}$

\section{Fatigue}

In moist helium, fatigue in Incoloy 800 was accompanied by an apparent increase in creep deformation and associated intergranular cracking. ${ }^{12}$ At $100 \mathrm{cpm}$, the crack grow th rate appeared to be independent of the test environment. At $30 \mathrm{cpm}$, two different effects occurred: at high stress amplitude a higher crack growth rate occurred in helium than in air, while at lower stress amplitude lower growth rates occurred due to crack branching. Fatigue cracks in helium were intergranular as opposed to transgranular cracks formed in air.

\section{Incoloy 802}

\section{Creep}

Only one reference to this alloy was found in the literature. ${ }^{9}$ At $850^{\circ} \mathrm{C}$ this alloy showed relatively low ductility in both helium and air, but this was attributed to the high carbon content. No other data were presented.

\section{Incoloy 807}

\section{Corrosion tests}

Incoloy 807 was found to corrode more rapidly in helium than in air. ${ }^{12}$ Huddle, ${ }^{7}$ on the basis of limited information and analysis of the fundamentals of gas-metal reactions, states that since Incoloy 807 is strengthened by tungsten it should be worthy of serious consideration for use in helium in high-temperature reactors (HTR). However, Sakakibara, Banno, and Sekino ${ }^{15}$ found that corrosion in helium was much more pronounced than in air. A loosely adhering scale was observed. 


\section{Inconel X}

\section{Corrosion tests}

After testing at 900 and $1010^{\circ} \mathrm{C}$ for times up to $3000 \mathrm{hr}$ in helium containing $3000 \mathrm{ppm} \mathrm{CO}$ and 3000 ppm $\mathrm{H}_{2}$, Inconel $\mathrm{X}$ showed severe intergranular attack and carburization, followed by oxidation. ${ }^{11}$ In general, it was concluded that Inconel $\mathrm{X}$ absorbs $\mathrm{CO}$ and that in this test sometime after $500 \mathrm{hr}$ of exposure an oxide layer developed that prevented the diffusion of carbon.

Bokros and Shoemaker ${ }^{17}$ ran tests with high-purity helium to which controlled amounts of $\mathrm{CO}, \mathrm{CO}_{2}$, and $\mathrm{H}_{2}$ were added. With an atmosphere of $5 \times 10^{-3}$ atm $\mathrm{CO}+5 \times 10^{-3}$ atm $\mathrm{H}_{2}$ no reactions occurred below $460^{\circ} \mathrm{C}$ after $1000 \mathrm{hr}$. At $704^{\circ} \mathrm{C}$ carburization occurred and a reaction layer of $(\mathrm{Cr}, \mathrm{Fe})_{2} \mathrm{O}_{3}$ was formed; at $843^{\circ} \mathrm{C}$ and above, internal oxidation was found along with a surfice layer of $(\mathrm{Cr}, \mathrm{Fe})_{2} \mathrm{O}_{3}+$ spinel. With an atmosphere of $2 \times 10^{-4}$ atm $\left(\mathrm{P}_{\mathrm{CO}}+2 \mathrm{P}_{\mathrm{CO}_{2}}\right)$, a reaction product of $\mathrm{Cr}_{2} \mathrm{O}_{3}+$ spinel was formed at 816 and $927^{\circ} \mathrm{C}$. At higher pressures $-10^{-2}$ atm $\left(\mathrm{P}_{\mathrm{CO}}+\mathrm{P}_{\mathrm{CO}_{2}}\right)-$ no surface corrosion product formed at $704^{\circ} \mathrm{C}$, although about 1.5 mils internal oxidation occurred and the sample carburized. At $927^{\circ} \mathrm{C}$ internal oxidation was found as well as a surface corrosion product of $(\mathrm{Cr}, \mathrm{Fe})_{2} \mathrm{O}_{3}+$ spinel. This alloy was considered to be the most promising high-strength nickel-base alloy tested, because it resisted severe carburization and oxidation better than the others and was ineffective in catalyzing the $\mathrm{CO}$ disproportionation reaction at impurity levels expected in the Maritime Gas-Cooled Reactor System.

\section{Creep-rupture}

Wall, Hengstenberg, and Gayley ${ }^{18}$ conclude that the long time rupture properties at $704^{\circ} \mathrm{C}$ are not seriously lowered in helium. Elongation values were low, which is claimed to reflect the marginal notch sensitivity of Inconel $\mathrm{X}$ in Grade A helium. At $816^{\circ} \mathrm{C}$, however, Shahinian ${ }^{19}$ found a slight reduction in rupture life for unnotched specimens in Grade A helium as compared to air. For notched specimens, rupture life was reduced by a factor of 3 . Impurities in the helium are believed to be responsible for the increased rupture life in helium compared to a vacuum environment. This work summarized the results of several different alloys; one conclusion drawn was that alloys of low ductility, such as Inconel X, are more affected by environment than are more ductile alloys.

Fatigue

Data were generated on fatigue in Grade A helium at $704^{\circ} \mathrm{C}$, but sufficient air fatigue data are not available to permit a comparison with the helium data. ${ }^{18}$

\section{Tensile properties}

Tensile property data were obtained at room temperature after treatment at 899 and $1010^{\circ} \mathrm{C}$ for 500 and $1500 \mathrm{hr}$ in helium containing $3000 \mathrm{ppm} \mathrm{CO}$ and $\mathrm{H}_{2} .{ }^{11}$ Comparisons were made with as-received material; but comparable tests were not run in air, so it is impossible to accurately assess the effect of the helium.

\section{Inconel 600}

\section{Corrosion tests}

Charlot and Westerman ${ }^{20}$ found no clear-cut pressure effect at $1200^{\circ} \mathrm{C}$. Spalling of the oxide layer occurred upon cooling from the test temperature. More detailed tests, run between 815 and $1038^{\circ} \mathrm{C}$ by Claudson and Westerman ${ }^{8}$ in 15 torr water vapor in helium, exhibited a tight adherent film, along with a 
penetrating intergranular attack. In general, the results indicate that the oxidation rates follow a parabolic rate law. This is substantiated by the tightly adherent layer.

At 650 and $750^{\circ} \mathrm{C}$, Bates, $\mathrm{B} \phi \mathrm{ye}$, and Wade ${ }^{9}$ found clear evidence of carburization of the surface layers in the form of increased precipitation within the grains. A thin oxide scale was also found. Some increase in intergranular carbide precipitation was seen after several thousand hours. In another investigation, Mazandarany ${ }^{6}$ found a very thin oxide scale, believed to be $\mathrm{Cr}_{2} \mathrm{O}_{3}$, at $649^{\circ} \mathrm{C}$. At 760 and $871^{\circ} \mathrm{C}$ and times to $10,000 \mathrm{hr}$, an oxide scale rich in $\mathrm{Cr}-\mathrm{Mn}-\mathrm{Ti}$ was found, along with aluminum-rich oxide intrusions which appear to occur preferentially at grain boundaries.

Creep

Testing to $10,000 \mathrm{hr}$ at 650 and $750^{\circ} \mathrm{C}$ in Dragon project helium indicates that creep strength is not significantly affected by the helium environment. ${ }^{9}$ Although no air testing was carried out, the results were assessed by comparison with manufacturers' standard data.

\section{Inconel 617}

\section{Corrosion tests}

In a study aimed primarily at creep rupture at $1000^{\circ} \mathrm{C}$, some decarburization and surface cracking was found. ${ }^{21}$ Bates, B $\phi y$ e, and Wade ${ }^{9}$, found only very slight surface oxidation along with some internal oxidation after $2000 \mathrm{hr}$ at $850^{\circ} \mathrm{C}$. Carbide precipitation appears more consistently in both the grains and grain boundaries in the helium-exposed than in the air-exposed specimen. Cook, Lupton, and Bates ${ }^{5}$ noted that surface oxide depths after $2000 \mathrm{hr}$ at $1000^{\circ} \mathrm{C}$ were less in helium than in air. Internal oxidation was less in helium than in air. However, Kondo, Kikuyama, and Shindo ${ }^{12}$ found that Inconel 617 corroded more rapidly in helium. Severe intergranular attack and internal oxidation were observed (with $60 \mu \mathrm{atm}$ $\mathrm{H}_{2} \mathrm{O}$ ). Weight change data showed a parabolic time dependence in both helium and air between 800 and $1000^{\circ} \mathrm{C}$.

At $649^{\circ} \mathrm{C}$ for times to $1000 \mathrm{hr}$, Mazandarany ${ }^{6}$ found a very thin oxide scale, believed to be $\mathrm{Cr}_{2} \mathrm{O}_{3}$. At 760 and $871^{\circ} \mathrm{C}$ he found an outer scale rich in $\mathrm{Cr}-\mathrm{Mn}-\mathrm{Al}-\mathrm{Ti}$, an inner scale rich in Al-Ti-Mn, and aluminumrich oxide intrusions. After exposure at $900^{\circ} \mathrm{C}$ in a simulated high-temperature gas-cooled reactor (HTGR) environment, Rosenwasser and Johnson ${ }^{2}$ found that the surface was covered with a duplex scale. The outer discontinuous bright scale was chromium-molybdenum carbide, rich in chromium and containing some nickel and cobalt. The inner, more continuous scale contained oxides rich in chromium and small amounts of titanium and aluminum. Below this scale, penetrating to a depth of $\sim 40 \mu \mathrm{m}$, were aluminum-rich oxides. These oxides penetrated a nickel-rich region depleted in aluminum, titanium, and chromium. The carbon content of this depleted region was four times greater than that of the interior of the specimen. After testing at $800^{\circ} \mathrm{C}$, the surface had a continuous multilayered scale consisting of alternating white (presumably carbide) and gray (presumably oxide) phases. Similar results were obtained at $650^{\circ} \mathrm{C}$, although to a lesser extent. Carburization was observed.

\section{Creep-rupture}

In high-purity helium and commercial-grade helium, Inconel 617 has almost the same creep behavior as in air. ${ }^{21}$ However, as the oxygen concentration is increased to $500 \mathrm{ppm}$, the alloy creeps at a higher rate. At $1000 \mathrm{ppm}$ the creep rate again decreases. The decrease in time to rupture was correlated with decarburization of the alloy. Bates, B Bye, and Wade ${ }^{9}$ saw little difference in strain rates between helium and air at 800 to $900^{\circ} \mathrm{C}$. Cook, Lupton, and Bates ${ }^{5}$ found that at $850^{\circ} \mathrm{C}$ the creep strength was slightly greater in air 
than in helium at higher stresses, although at lower stresses there was no apparent difference. On the other hand, Rosenwasser and Johnson ${ }^{2}$ report that in a simulated HTGR environment the creep rate was higher by an order of magnitude than for air data. Apparently severe carburization affected creep resistance.

\section{Tensile properties}

Rosenwasser and Johnson ${ }^{2}$ present tensile data from samples treated in helium, but no comparisons with air data were made due to unavailability of data.

\section{Impact properties}

A decrease in impact strength was found ${ }^{2}$ which is consistent with thermal aging data in air.

\section{Inconel 625}

\section{Corrosion tests}

The results on this alloy are conflicting. Claudson and Westerman ${ }^{8}$ report that oxidation rates follow a parabolic rate law. The alloy exhibited a tight adherent film, along with a significant amount of intergranular attack and internal oxidation, after treatment in 15 torr water vapor in Grade A helium between 815 and $1038^{\circ} \mathrm{C}$. Carburization was found after $5000 \mathrm{hr}$ at $850^{\circ} \mathrm{C}$, as well as art oxide formation which is considered to be an unprotective surface oxide. ${ }^{9}$

At $750^{\circ} \mathrm{C}$, Cook, Lupton, and Bates ${ }^{5}$ found only thin surface oxides. Intergranular oxidation was found only in strained specimens, probably due to oxidation in growing cracks. There was no evidence for subsurface carburization from helium. On the other hand, Huddle ${ }^{7}$ found no reaction and no decarburization.

\section{Creep-rupture}

At short time periods (2000 to $6000 \mathrm{hr}$ ), no difference in strength levels between helium and air was found at 750 and $850^{\circ} \mathrm{C}$ in specimens solution-treated at $980^{\circ} \mathrm{C} .{ }^{9}$ In specimens solution-treated at $1150^{\circ} \mathrm{C}$, some differences were found: strain rates were lower in helium than in air, and the samples ruptured under comparable stress/time conditions but with lower ductility in helium. This latter effect is believed to be due to carburization. Cook, Lupton, and Bates ${ }^{5}$ report essentially the same data and suggest that the difference in behavior may be associated with easier nucleation of cracks in air, as opposed to easier crack propagation in helium.

\section{Inconel 702}

\section{Corrosion tests}

In an atmosphere of helium plus 15 torr water vapor, tests run between 815 and $1038^{\circ} \mathrm{C}$ resulted in relatively high weight gains combined with a significant amount of intergranulcir attack and intergranular oxidation. $^{8}$ In an atmosphere of helium plus $5 \times 10^{-3}$ atm $\mathrm{CO}+5 \times 10^{-3} \mathrm{~atm} \mathrm{H}_{2}$, Bokros and Shoemaker ${ }^{17}$ found no reaction below $443^{\circ} \mathrm{C}$ after $1000 \mathrm{hr}$. At $677^{\circ} \mathrm{C}$ internal oxidation and a corrosion product of $(\mathrm{Cr}, \mathrm{Fe})_{2} \mathrm{O}_{3}$ were found, and at $827^{\circ} \mathrm{C}$ the sample was completely carburized with 4 mils internal oxidation and an oxide layer, $(\mathrm{Cr}, \mathrm{F})_{2} \mathrm{O}_{3}$. 
Inconel 718

\section{Corrosion tests}

Only one reference to this alloy was found. ${ }^{8}$ Tests were conducted under an atmosphere of 15 torr water vapor in Grade A helium between 815 and $1038^{\circ} \mathrm{C}$. A significant amount of intergranular at tack and internal oxidation were found. Considerable weight loss of the sample resulted at $1038^{\circ} \mathrm{C}$; this is believed to be caused by oxide volatilization. Spalling of the oxide layer could also have caused the weight loss.

\section{Hastelloy B}

\section{Corrosion tests}

A minimized overall corrosion rate was found, ${ }^{12}$ presumably due to the absence of chromium. The surface oxide was composed mainly of manganese, with a trace of chromium. Intergranular attack was also present and is believed due to the oxidation of impurities - notably silicon - segregated at the boundaries.

\section{Hastelloy C}

\section{Corrosion tests}

Tests were conducted between 815 and $1038^{\circ} \mathrm{C}$ under an atmosphere of 15 torr water vapor in Grade A helium. ${ }^{8}$ Under these conditions the alloy showed very little weight gain. This situation is attributed to the formation of a tight, adherent oxide film on the surface of the specimen. Little or no grain boundary penetration or internal oxidation occurred.

\section{Stress-rupture}

The stress-rupture life was always greatest in air. ${ }^{22}$ It decreased in the order of air, special-purity helium $\left(0.2\right.$ mole $\% \mathrm{H}_{2}, 0.1$ mole $\left.\% \mathrm{~N}_{2}\right), 67 \%$ helium $+33 \% \mathrm{H}_{2}$, and helium plus oil contamination. The effects noted were differences in the amount of intergranular cracking and differences in the time to failure.

\section{Hastelloy $\mathbf{N}$}

\section{Corrosion tests}

Claudson and Pessl $1^{23}$ obtained a slight weight gain from $500-\mathrm{hr}$ tests at $1060^{\circ} \mathrm{C}$ in flowing helium that had been passed over graphite heated to 450 to $500^{\circ} \mathrm{C}$. Claudson and Westerman ${ }^{8}$ conducted tests in helium plus 15 torr water vapor between 815 and $1038^{\circ} \mathrm{C}$; Hastelloy $\mathrm{N}$ showed superior corrosion resistance. The good oxidation resistance of this alloy is attributed to a tight oxide film on the surface of the specimen, with little or no grain boundary penetration or internal oxidation. Parabolic rate law curves are indicated.

\section{Hastelloy R-235}

\section{Corrosion tests}

In general, this alloy shows poor oxidation resistance in helium atmospheres. At $1060^{\circ} \mathrm{C}$ in helium passed over graphite, samples of Hastelloy R-235 showed considerable weight gain. ${ }^{23}$ Under helium plus 15 torr water vapor, Hastelloy R-235 showed the worst attack of all the alloys tested. ${ }^{8}$ The high weight gains that occur are believed to be due to severe intergranular attack. The oxidation attack spread from the grain boundaries into the material matrix after the penetration occurred. 


\section{Hastelloy S}

\section{Corrosion tests}

Mazandarany ${ }^{6}$ used purified helium to which he added $\mathrm{H}_{2}+\mathrm{CH}_{4}$ or $\mathrm{H}_{2}+\mathrm{CH}_{4}+\mathrm{CO}$. At $649^{\circ} \mathrm{C}$ a very thin oxide scale - believed to be $\mathrm{Cr}_{2} \mathrm{O}_{3}$ - was found for times to $1000 \mathrm{hr}$. At 760 and $871^{\circ} \mathrm{C}$ atio times to $10,000 \mathrm{hr}$, the oxide scale was rich in chromium, manganese, and aluminum. At the longer times, aluminum-rich oxide intrusions were found.

\section{Hastelloy $\mathrm{X}$}

\section{Corrosion tests}

Under high-purity helium or vacuum conditions at $1150^{\circ} \mathrm{C}$, weight losses were observed ${ }^{24-25}$ which were attributed to evaporation of the more volatile alloy constituents, notably chromium. Increasing the pressure of high-purity helium decreased the evaporation rate. Evaporation rates increased with increasing temperature. ${ }^{26}$ In addition, evaporation rates increased sharply with gas flow rate between 300 and 500 fps. At lower temperatures, more direct reactions with impurities in the helium appear to have occurred: at $925^{\circ} \mathrm{C}$ a weight gain due to oxidation ${ }^{24}$ was found, as compared to a weight loss at $1150^{\circ} \mathrm{C}$; at $700^{\circ} \mathrm{C}$ after $1000 \mathrm{hr}$, thin surface oxides were found, with some evidence of spalling and occasional penetration associated with molybdenum carbide particles.

Carburization occurred near the surface of helium-tested specimens.. 5 This extended to as much as $100 \mu \mathrm{m}$ after $10,000 \mathrm{hr}$ at $750^{\circ} \mathrm{C}$. Intergranular oxidation of 20 to $40 \mu \mathrm{m}$ occurred after $10,000 \mathrm{hr} .^{5}$ Mazandarany ${ }^{6}$ found a very thin oxide scale at $649^{\circ} \mathrm{C}$, which is believed to be $\mathrm{Cr}_{2} \mathrm{O}_{3}$. At 7.60 and $871^{\circ} \mathrm{C}$ an outer scale rich in chromium and manganese was found, with an inner scale ricli in chromium, aluminum, and manganese, aluminum-rich oxide intrusions, and a metallic phase in the scale rich in iron, nickel, and cobalt.

Wunderlich and Baker ${ }^{11}$ concluded that, based on mechanical and metallographic examination, Hastelloy $\mathrm{X}$ was the least affected of all the materials tested at 899 and $1010^{\circ} \mathrm{C}$. Kondo, Kikuyama, and Shindo ${ }^{12}$ found lower rate constants in helium than in air and attributed the improved performance in helium to the low titanium content of the alloy.

\section{Creep-rupture}

Little or no difference was found between tests run in helium and air or in the time to reach $0.5 \%, 1 \%$, or $5 \%$ strain at $750^{\circ} \mathrm{C},{ }^{9}$ time to tertiary creep, or rupture ductility at $750^{\circ} \mathrm{C}^{5}$ Similar results were found by Wolwowicz ${ }^{16}$ and Lystrup. ${ }^{27}$

\section{Tensile properties}

Mechanical property tests and metallography led Wunderlich and Baker ${ }^{11}$ to conclude that Hastelloy $\mathrm{X}$ was one of the materials least affected by exposure to helium at 899 and $1010^{\circ} \mathrm{C}$. However, no comparable air data were included.

\section{Hastelloy X-280}

\section{Corrosion tests}

Oxidation rates of Hastelloy X-280 in 15 torr water vapor in Grade A helium follow a parabolic rate law. A tight adherent oxide film forms on the surface of the specimen, with ro grain boundary penetration or internal oxidation. No evidence of oxide spalling was found, although thermal cycling caused 
spalling. ${ }^{20}$ Oxidation rate is dependent on the one-fifth power of the oxygen pressure. ${ }^{28}$ Oxidation proceeds at a lower rate in carbon oxides and water vapor than in air or oxygen. ${ }^{20}$ The probability of carbide formation in the base metal due to dissociation reactions of $\mathrm{CO}_{2}, \mathrm{CO}$, or $\mathrm{CH}_{4}$ decreases sharply if the atmosphere is oxidizing. ${ }^{20}$

\section{Nimonic 75}

\section{Corrosion tests}

Nimonic 75 was studied extensively by Knutsen, Condé, and Piene, ${ }^{29}$ using partial pressures from 0.01 torr to $1 \mathrm{~atm}$ of the gases $\mathrm{CO}_{2}, \mathrm{H}_{2} \mathrm{O}, \mathrm{CO}, \mathrm{CH}_{4}$, and $\mathrm{H}_{2}$.

In $\mathrm{CO}_{2}$, the reaction was comprised of surface oxide formation, decarburization, and evaporation. The mode of reaction is a function of temperature, partial pressure of $\mathrm{CO}_{2}$, and time of reaction. The surface oxide $\left(\mathrm{Cr}_{2} \mathrm{O}_{3}+\mathrm{NiCr}_{2} \mathrm{O}_{4}\right)$ increases as the partial pressure of $\mathrm{CO}_{2}$ increases. At high pressures, chromium is preferentially oxidized, forming a uniform coherent scale. At lower partial pressures, less uniform and less protective scales are formed, and chromium is lost by evaporation. This may also involve the decomposition of chromium carbides. Similar reactions were found in partial pressures of 0.01 to 7 torr water vapor, although the kinetics were slower.

In $\mathrm{CO}$, at lower pressures a weight loss occurred at 900 and $1000^{\circ} \mathrm{C}$ and was attributed to evaporation of chromium. At 10 torr $\mathrm{CO}$ and $1000^{\circ} \mathrm{C}, \mathrm{Cr}_{7} \mathrm{C}_{3}$ was found at the surface; but at lower pressures $\mathrm{x}$-ray diffraction studies found only reflections of the alloy phase. At $900^{\circ} \mathrm{C}$ only the alloy phase was found at 0.01 torr, but at higher pressures $\mathrm{Cr}_{2} \mathrm{O}_{3}$ was found. At $750^{\circ} \mathrm{C}$ only the alloy phase was found.

In $\mathrm{CH}_{4}$, weight gains under all conditions were the result of carbon increase and subsequent chromium carbide precipitates. Titanium was enriched at the surface, probably because of the formation of titanium carbides. Manganese was depleted, possibly due to evaporation.

In hydrogen, no reaction products could be observed. At 900 and $1000^{\circ} \mathrm{C}$ weight losses occurred at all pressures, presumably due to evaporation.

With mixtures of gases $\left[\mathrm{CO}+\mathrm{H}_{2}(1: 1)\right]$, weight gains were observed at all pressures at $750^{\circ} \mathrm{C}$. At $900^{\circ} \mathrm{C}$ weight losses were observed at 0.25 and 0.5 torr, with weight gains at higher pressures. Weight losses are associated with chromium evaporation and weight gains with $\mathrm{Cr}_{2} \mathrm{O}_{3}$ formation.

When a mixture of $\mathrm{N}_{2}+\mathrm{CO}+\mathrm{H}_{2}+\mathrm{H}_{2} \mathrm{O}+\mathrm{CH}_{4}$ (1:3:3:0.5:0.5) was used, weight gains were observed at all pressures. This was verified by the formation of an oxide layer of $\mathrm{Cr}_{2} \mathrm{O}_{3}$ and traces of $\mathrm{NiCr}_{2} \mathrm{O}_{4}$. Depletion of chromium carbide precipitates also occurred.

\section{Tensile tests}

In 0.1 torr $\mathrm{CO}_{2}$, a relatively large decrease in the ultimate tensile strength occurred with time at temperatures between 850 and $1050^{\circ} \mathrm{C}$. This corresponds to the depletion of chromium carbides, followed at later times by surface and grain boundary oxidation. After one year at $750^{\circ} \mathrm{C}$ under 0.1 torr $\mathrm{CO}$, the ultimate tensile strength decreased 12 to $15 \%$ compared to the as-received value, although the elongation increased.

Under carburizing conditions the ultimate tensile strength initially decreases, possibly due to the initial reduction of the thin oxide film by the carbon in the specimen. This is followed by an increase in the ultimate tensile strength from carburization due to the cracking of $\mathrm{CH}_{4}$ and the subsequent diffusion of the carbon into the specimen. A final gradual decrease in the ultimate tensile strength with time is probably due to the gradual accumulation of precipitates along the grain boundaries in the alloy.

Exposure to 0.2 torr $\mathrm{CO}+\mathrm{H}_{2}(1: 1)$ at $900^{\circ} \mathrm{C}$ resulted in only a small decrease in ultimate tensile strength and proportional limit and a slight increase in percent elongation, with times to $300 \mathrm{hr}$. 
When a mixture of $\mathrm{N}_{2}+\mathrm{CO}+\mathrm{H}_{2}+\mathrm{H}_{2} \mathrm{O}+\mathrm{CH}_{4}(1: 3: 3: 0.5: 0.5)$ was used at 0.3 torr and $900^{\circ} \mathrm{C}$, the ultimate tensile strength decreased from $84 \mathrm{~kg} / \mathrm{mm}^{2}$ to about $60 \mathrm{~kg} / \mathrm{mm}^{2}$ after $200 \mathrm{hr}$ and the percent elongation increased. This corresponds to the decrease in ultimate tensile strength with progressive decarburization.

\section{Nimonic 80A}

\section{Corrosion tests}

In an inert gas (argon) containing $400 \mu$ atm $\mathrm{CO}, 400 \mu$ atm $\mathrm{H}_{2}$, and variable water vapor, the corrosion resistance of Nimonic $80 \mathrm{~A}$ at $800^{\circ} \mathrm{C}$ was relatively poor. ${ }^{13}$ High weight gains were associated with internal attack, and significant oxidation accompanied an increase in water vapor level. There is some question as to whether or not this alloy formed a protective oxide film. The carburization rate of Nimonic $80 \mathrm{~A}$ decreased only slightly with methane pressure.

On the other hand, Cook, Lupton, and Bates ${ }^{5}$ found that the depth of oxide penetrations was 15 to 20 $\mu \mathrm{m}$ after exposure at $800^{\circ} \mathrm{C}$ for $10,000 \mathrm{hr}$. This was considerably less than for Incoloy 800 . At $900^{\circ} \mathrm{C}$ and $8000 \mathrm{hr}$ the oxide penetration was about $40 \mu \mathrm{m}$. However, weight gains were about four times higher than expected from the oxide depths, suggesting an as-yet-unidentified corrosion mechanism in this material. Some carburization was also noted.

\section{IN-100}

\section{Corrosion tests}

Information on this alloy is due to the work of Rosenwasser and Johnson 2 . There was no corrosion product at $650^{\circ} \mathrm{C}$ after $3000 \mathrm{hr}$. At $800^{\circ} \mathrm{C}$ there was a 1.5 to $3.0-\mu \mathrm{m}$-thick oxide layer with a 10 to $18-\mu \mathrm{m}$ denuded zone and a 20 to $80-\mu \mathrm{m}$ zone containing heavy carbide precipitates. At $900^{\circ} \mathrm{C}$ the oxide layer was 4 to $5 \mu \mathrm{m}$ thick, the denuded zone was 21 to $27 \mu \mathrm{m}$ thick, and the carbide precipitation zone was 40 to $120 \mu \mathrm{m}$ thick: Carburization was observed. The surface layer was a continuous, lijcally intruding gray scale, identified as an oxide mostly composed of aluminum with small amounts of titanium and chromium. Carbon enrichment occurred in the scale. Below this scale was a low-carbon nickel-rich layer which was also rich in chromium, molybdenum, and cobalt and depleted in aluminum and titanium. At $800^{\circ} \mathrm{C}$ the outer layer was richer in titanium and chromium than it was at $900^{\circ} \mathrm{C}$.

\section{Creep-rupture}

The estimated minimum creep rate for $1 \mathrm{~N}-100$ at 800 and $900^{\circ} \mathrm{C}$ agrees reasonably well with published air values.

\section{Tensile tests}

Tensile property data are given, ${ }^{2}$ but no comparison with air data is made. However, it is expected that neither the thin oxide layer nor the precipitated carbides would have much effect on room temperature tensile properties.

\section{Impact tests}

Impact property data are given, ${ }^{2}$. but no comparison with air data is made. 


\section{IN-102}

\section{Corrosion tests}

Bates, $B \phi y e$, and Wade ${ }^{9}$ found only limited corrosion effects in the helium environment after exposure at $750^{\circ} \mathrm{C}$ for $10,000 \mathrm{hr}$. There was considerably less surface and internal oxidation than for other alloys and only slight evidence of carburization. Cook, Lupton, and Bates ${ }^{5}$ found much less oxide penetration in a laboratory alloy containing $0.1 \%$ aluminum and $0.1 \%$ titanium, as compared to a commercial heat containing $1 \%$ aluminum and $1 \%$ titanium. The oxide on the commercial alloy was three times as thick as that on the laboratory alloy. They conclude that the difference is due to the aluminum and titanium contents.

\section{Creep-rupture}

Comparison with manufacturers' air data indicates that there is no difference in creep properties between helium and air for exposure times to $10,000 \mathrm{hr}$ with a stress of 50 to $65 \mathrm{~N} / \mathrm{mm}^{2}$. However, helium properties are marginally lower for higher stresses and shorter duration tests.

\section{IN-586}

\section{Corrosion tests}

Preliminary tests show that this alloy has good corrosion properties in HTR helium. ${ }^{9}$

\section{IN-713 LC}

\section{Corrosion tests}

Little or no surface oxidation was found at either 750 or $800^{\circ} \mathrm{C} .^{9}$ However, internal oxidation was evident in the form of a fine needle-like penetration. This oxidation appeared to be related to the cast dendritic structure, and it spread to a more uniform depth at longer test times. Clear evidence of carburization in the form of a subsurface zone of carbide precipitation was noted.

\section{IN-713}

\section{Corrosion tests}

Rosenwasser and Johnson ${ }^{2}$ have studied this alloy in controlled-impurity helium. A sample tested at $900^{\circ} \mathrm{C}$ was covered with a thin $(1$ to $2 \mu \mathrm{m})$ continuous oxide scale which intruded into a 25 to $40-\mu \mathrm{m}$-thick depleted region. The composition of the oxide scale was spotty; in some cases it contained only aluminum, in others it contained aluminum and chromium, and in others it contained aluminum, chromium, and titanium. The depleted region below the oxide scale was enriched in nickel and depleted in aluminum and titanium. The oxide scale was enriched in carbon and intruded 5 to $15 \mu \mathrm{m}$ into the depleted zone which was 20 to $25 \mu \mathrm{m}$ deep. After testing at $800^{\circ} \mathrm{C}$, the results were similar but less extensive. After $650^{\circ} \mathrm{C}$ exposure, the surface layer was very thin and the depleted zone was about $5 \mu \mathrm{m}$ thick.

\section{Creep-rupture}

Helium creep data at $800^{\circ} \mathrm{C}$ were identical with air data, although at $900^{\circ} \mathrm{C}$ the creep rate in helium was higher than in air.

\section{Tensile tests}

Tensile data are reported but comparable air data are not available. Considering the small amount of oxidation, no effect from the oxide or carbide layers is expected. 


\section{Impact tests}

Large decreases in the impact strength of IN-713 are attributed to the precipitation of carbides and sigma phase. These decreases are consistent with data on thermal aging in air.

\section{IN-738}

\section{Corrosion tests}

At 800 and $900^{\circ} \mathrm{C}$, Rosenwasser and Johnson ${ }^{2}$ found a 1 to $2-\mu \mathrm{m}$ continuous, locally intruding gray scale. This scale was rich in aluminum and titanium, with some chromium in the outer scale. The outer scale was also richer in titanium than the deeper intruded scale. Below the outer layer was a nickel-rich region depleted in aluminum and titanium. Carburization was also observed. At $600^{\circ} \mathrm{C}$ the oxide layer was about 1 to $2 \mu \mathrm{m}$ thick with $\sim 4-\mu \mathrm{m}$ intrusions and a depleted layer $<10 \mu \mathrm{m}$ thick.

\section{Creep rupture}

Creep data in controlled-impurity helium are given, but no comparison with air data is given.

\section{Tensile tests}

Tensile data are given, but no comparable air data are given.

\section{Inco 700}

\section{Creep-rupture}

Helium data are similar to published air data at $816^{\circ} \mathrm{C}$.

\section{Fatigue}

The unnotched-to-notched fatigue strength ratio $\mathrm{K}_{\mathrm{f}}$ in Grade A helium is 2.0 and the notch sensitivity is $0.34 .{ }^{18}$ No comparisons with air data were made.

\section{Inco 713C}

\section{Creep-rupture}

Creep-rupture properties at $704^{\circ} \mathrm{C}$ in Grade A helium are comparable to published air data. A 500 -hr stress-range diagram for helium revealed a straight-line relationship for Inco $713 \mathrm{C}$ at $704^{\circ} \mathrm{C}$, which indicates an adverse effect on the mean stress of even very small values of alternating stress amplitude. This is indicative of the superior rupture strength of coarse-grained material under static stress and the inferior strength of this material under cyclic loading.

\section{Nickel}

\section{Creep-rupture}

At $600^{\circ} \mathrm{C}$, the creep-rupture life drops rather rapidly with initial increases in oxygen pressure until about $10^{-4}$ torr oxygen. ${ }^{30}$ Above this pressure there is no further change! The minimum creep rate increases up to about $10^{-4}$ torr and then levels off. At $510^{\circ} \mathrm{C}$ the results are similar; scatter in the data makes it difficult to determine the value of the critical pressure, but it appeats to be $10^{-3}$ to $10^{-4}$ torr oxygen.

At low stresses and higher temperatures, nickel is stronger in air, but at high stresses and low temperature it is stronger in vacuum. ${ }^{31}$ Two competing processes are proposed: oxidation strengthens the metal, 
while adsorption of gas lowers the surface energy relative to that in vacuum and reduces the work required to propagate a crack. The process which controls in any given instance is determined by stress and temperature.

\section{Fatigue}

At $816^{\circ} \mathrm{C}$ there was a leveling off of the $\log \mathrm{N}$ vs $\log \mathrm{P}_{\mathrm{O}_{2}}$ curve at $10^{-5}$ torr, probably due to saturation effects. ${ }^{32}$ Another descent starts at $10^{-3}$ torr, due to the diffusion of oxygen along grain boundaries ahead of the crack. At $10^{2}$ torr, oxidation strengthening produces an upturn.

At $300^{\circ} \mathrm{C}$ the saturation point is displaced to higher pressure $\left(10^{-3}\right.$ torr $)$. Fatigue lives in inert gases are comparable to those in oxygen, which suggests that the level of reactive impurities in inert atmospheres is sufficient to saturate the crack surfaces. For nickel, changes in crack initiation and growth with gas pressure depends on temperature. At $300^{\circ} \mathrm{C}$, there is evidence of an increase in the rate of crack initiation, while at $816^{\circ} \mathrm{C}$ only the rate of propagation is increased.

\section{"A" Nickel}

\section{Corrosion tests}

Bokros and Shoemaker ${ }^{17}$ studied this material under varying concentrations of $\mathrm{CO}$ and $\mathrm{CO}_{2}$. At 816 and $927^{\circ} \mathrm{C}$ under an atmosphere of $2 \times 10^{-4}$ atm $\left(\mathrm{P}_{\mathrm{CO}}+2 \mathrm{P}_{\mathrm{CO}_{2}}\right)$ no surface reaction was observed, although some decarburization was noted after $500 \mathrm{hr}$. At $10^{-2}$ atm $\left(\mathrm{P}_{\mathrm{CO}}+2 \mathrm{P}_{\mathrm{CO}_{2}}\right)$ and 677 and $927^{\circ} \mathrm{C}$, no corrosion products were formed.

Under an atmosphere of $5 \times 10^{-3}$ atm $\mathrm{CO}$ and $5 \times 10^{-3}$ atm $\mathrm{CO}_{2}$, no surface corrosion product was observed at temperatures up to $916^{\circ} \mathrm{C}$ after $1000 \mathrm{hr}$. Between 493 and $916^{\circ} \mathrm{C}$, grain boundary at tack was observed. In one case, graphite precipitation on the metal was found.

Nickel catalyzes $\mathrm{CO}$ disproportionation at high concentrations of $\mathrm{CO}$. It does not catalyze free carbon deposition at levels of $10^{-2}$ atm $\mathrm{CO}$ or less. The temperature dependence of carbon solubility causes graphitization during thermal cycling. At high temperature, nickel becomes saturated with carbon, which precipitates when the nickel is cooled. This "graphitization" can occur over a very narrow temperature range and will ultimately cause deteriorization during thermal cycling.

\section{Haynes 25}

\section{Corrosion tests}

Most of the information available on Haynes 25 has come from the work of Westerman and coworkers: ${ }^{8,20,33}$ Chemical reaction and evaporation are the two most important degradation mechanisms observed to date.

Haynes 25 oxidizes according to a parabolic rate law. $8 ; 3$. In flowing Grade A helium at $1038^{\circ} \mathrm{C}$, some internal oxidation was found along with an oxide scale. Between 815 and $1038^{\circ} \mathrm{C}$ in 15 torr water vapor in Grade A helium, Haynes 25 formed a tight adherent oxide film on the surface, with little or no grain boundary penetration or internal oxidation. Spalling was not observed at elevated temperature, but under thermal cycling spalling did occur. Oxidation in air at $1000^{\circ} \mathrm{C}$ was appreciably higher than in low-pressure oxygen. ${ }^{34}$ However, oxidation in $3 \mathrm{~mm}$ oxygen was somewhat higher than in $25 \mathrm{~mm}$ oxygen, suggesting a minimum in the oxidation rate-pressure relationship.

In high-purity helium $\left(<1\right.$ ppm O $\left.\mathrm{O}_{2}+\mathrm{N}_{2}+\mathrm{H}_{2}+\mathrm{CO}+\mathrm{H}_{2} \mathrm{O}+\mathrm{CH}_{4}\right)$ at $1149^{\circ} \mathrm{C}$, a weight loss was found due to evaporation - primarily of chromium. ${ }^{24}$ This evaporation was less than that found in vacuum. 
Other gaseous contaminations can also affect the alloy. Trace amounts of $\mathrm{CH}_{4}, \mathrm{CO}_{2}, \mathrm{CO}$, and $\mathrm{H}_{2} \mathrm{O}$ can be harmful if their concentration reaches a high enough level. ${ }^{20}$ The resulting effect can be either oxidation or carburization, depending on the relative amounts of the various reactive species in the system.

\section{Monel}

\section{Corrosion tests}

Under an atmosphere of $2 \times 10^{-4} \mathrm{~atm}\left(\mathrm{P}_{\mathrm{CO}}+2 \mathrm{P}_{\mathrm{CO}_{2}}\right)$ no corrosion product was found after $406 \mathrm{hr}$ at 816 and $927^{\circ}{ }^{\circ} .^{17}$ Intergranular attack and some decarburization were noted. With an atmosphere of $10^{-2}$ atm $\left(\mathrm{P}_{\mathrm{CO}}+2 \mathrm{P}_{\mathrm{CO}_{2}}\right)$, no surface corrosion product was observed between 616 and $927^{\circ} \mathrm{C}$, although a fine grain boundary precipitate was found at $927^{\circ} \mathrm{C}$. Some decarburization was also observed above $799^{\circ} \mathrm{C}$. Under an atmosphere of $5 \times 10^{-3} \mathrm{~atm} \mathrm{CO}+5 \times 10^{-3}$ atm $\mathrm{H}_{2}$, no surface reaction products were seen at temperatures up to $916^{\circ} \mathrm{C}$. Above $760^{\circ} \mathrm{C}$ some grain boundary attack was found. Decarburization occurred at all temperatures.

Monel can catalyze $\mathrm{CO}$ disproportionization at high concentrations of $\mathrm{CO}$, kiut it does not catalyze free carbon deposition at levels of $10^{-2}$ atm $\mathrm{CO}$ or less. Monel has a lower solubility for carbon than does nickel; Monel does not graphitize significantly during thermal cycling. It does, however, suffer from extensive grain boundary àttack in the presence of mixtures of $\mathrm{CO}, \mathrm{CO}_{2}, \mathrm{H}_{2}, \mathrm{H}_{2} \mathrm{O}$, and $\mathrm{O}_{2}$. The presence of this grain boundary attack may be attributed to alternate oxidizing and reducing conditions in gas mixtures.

\section{Nichrome}

\section{Corrosion tests}

Charlot and Westerman ${ }^{35}$ found that nichrome samples were prone to oxicle spallation. Metal loss due to evaporation of chromium was experienced after $24 \mathrm{hr}$ at $1121^{\circ} \mathrm{C}$. In this work, a vacuum was used to simulate ultrapure helium.

Further work by Charlot and Westerman ${ }^{33}$ indicates that the kinetics of the nichrome oxidation can best be described by a cubic rate expression:

$$
\mathrm{w}^{3}=\mathrm{kt}
$$

where $w$ is the weight change, $t$ is time, and $k$ is a constant that increases with pressure and temperature. At $1220^{\circ} \mathrm{C}$ in $140 \mu \mathrm{m}$ oxygen, a sample oxidized slightly and after $42 \mathrm{hr}$ began to lose weight, presumably due to evaporation of chromium oxide. In general, nichrome is more oxidation-resistant than either Hastelloy X-280 or Haynes 25. The scale retained on cooling was found to consist of both chromium and nickel oxides. No intergranular penetration or subsurface oxidation was found, although void areas were found near the metal-oxide interface similar to those found in the other superalloys.

\section{DM-45}

\section{Creep-rupture}

Shahinian ${ }^{19}$ conducted a series of tests in various atmospheres including air, oxygen, nitrogen, helium, and vacuum. Grade A helium was used. The rupture life of both the notched and the unnotched specimens was longer in air than in helium. Accordingly, the minimum rate was lower in air, but the elongation was about the same for the two environments. The notch sensitivity (ratio of notched rupture life to unnotched rupture life) of DM-45 did not appear to be affected to any great extent by environment. In air this ratio is 1.60 , while in helium it is 1.47 . 
Specimens tested in air contained a few cracks near the fracture; those tested in helium showed many intercrystalline cracks along the gage length. In addition, the helium-tested specimens developed a "grain" structure on the surface, in the form of surface roughening.

\section{X RN 72}

\section{Corrosion tests}

After exposure at 750 and $800^{\circ} \mathrm{C}$ in a simulated HTR environment, considerable structural change occurred within the alloy and at the specimen surfaces. ${ }^{9}$ Fairly thick uniform, porous surface oxidation occurred, with some localized internal intergranular oxidation. Extensive internal carbide precipitation occurred, primarily at $750^{\circ} \mathrm{C}$ at grain boundaries and on slip planes. Similar precipitation through the entire thickness occurred after $12,000 \mathrm{hr}$, which is attributed to carburization from the helium environment. Some internal precipitation occurred in air but was far less extensive than in the simulated HTR environ. ment.

\section{Creep-rupture}

The changes described above had little or no effect on the creep properties, inasmuch as comparable creep behavior was found in both environments.

\section{R 72}

\section{Corrosion tests}

There was clear evidence for carburization of $12 \mathrm{R} 72$ as a direct result of testing in helium at 650 to $800^{\circ} \mathrm{C}^{10}{ }^{10}$ Helium-tested samples were carburized throughout their cross section, whereas air-tested samples were not. Intergranular oxidation and carburization occurred simultaneously.

\section{Creep-rupture}

Creep rates in helium were substantially less than in air. ${ }^{10}$ Simultaneous intergranular oxidation and carburization did not produce any detrimental effects on creep resistance or any recognizable tendency for earlier creep cracking, even in cases of gross carburization. This alloy showed good strength, although its corrosion resistance was poor.

\section{Sanicro $32 \mathrm{X}$}

\section{Creep-rupture}

Creep tests gave times to rupture of 855 to $1560 \mathrm{hr}$ in both helium and air. ${ }^{9}$

\section{Rene 41}

\section{Corrosion tests}

Specimens were exposed to helium containing $3000 \mathrm{ppm} \mathrm{CO}$ and $\mathrm{H}_{2}$ for times to $1500 \mathrm{hr}$ and temperatures of 899 and $1010^{\circ} \mathrm{C}^{11}$ Severe intergranular attack and carburization were found, followed by oxidation. Rene 41 was shown to absorb $\mathrm{CO}$, and some time after $500 \mathrm{hr}$ it developed an oxide layer that prevented the diffusion of carbon. 


\section{Tensile tests}

Some progressive loss in tensile strength and yield strength was noted ${ }^{11}$ ffter $1500 \mathrm{hr}$ at 899 and $1010^{\circ} \mathrm{C}$, but it is not clear whether this decrease was due to the helium atmosphere or to overaging. No comparable air data were given.

\section{Rene 100}

\section{Corrosion tests}

The results of testing this alloy in controlled-impurity helium were virtually identical with those obtained for IN-100. ${ }^{2}$

\section{Creep-rupture}

The estimated creep rate for Rene 100 is not significantly different from air creep rates calculated from available literature data. ${ }^{2}$

\section{Tensile tests}

Tensile property data are given, ${ }^{2}$ but no comparison with air data is made. However, it is expected that neither the thin oxide layer nor the precipitated carbides would have much effect on room temperature tensile properties of this alloy.

\section{MM-004}

\section{Corrosion tests}

After exposure at $900^{\circ} \mathrm{C}$ to controlled-impurity helium, ${ }^{2}$ the surface contained a thin (1 to $\left.3 \mu \mathrm{m}\right)$, generally continuous oxide scale which was rich in aluminum and contained traces of titanium and chromium. An intruded oxide 10 to $30 \mu \mathrm{m}$ thick was also rich in aluminum and contained some nickel, chromium, and molybdenum and/or niobium. A denuded zone 40 to $50 \mu \mathrm{m}$ thick was found to be enriched in nickel and depleted in aluminum. Enrichment of carbon was found in the denuded zone. At $800^{\circ} \mathrm{C}$ the layers were similar but less extensive. The scale intruded $\sim 20 \mu \mathrm{m}$ into the depleted zone, which was 20 to $30 \mu \mathrm{m}$ thick. At $650^{\circ} \mathrm{C}$ only an extremely thin scale was found.

\section{Tensile tests}

Tensile data are given, but no comparisons with air data are made due to the unavailability of data. ${ }^{2}$

\section{M-21}

\section{Corrosion tests}

After exposure at $900^{\circ} \mathrm{C}$ in controlled-impurity helium, ${ }^{2}$ the surface contained a very thin $(\sim \mu \mathrm{m})$ discontinuous oxide scale which intruded 20 to $40 \mu \mathrm{m}$ into a nickel-rich aluminum-depleted region. The surface and the intruded oxide were rich in aluminum and contained some chromium near the surface. At $800^{\circ} \mathrm{C}$ these zones were appreciably thinner, and at $650^{\circ} \mathrm{C}$ no intrusions were observed and the depleted zone was extremely shallow. Heavy carbide precipitation also occurred near the surface.

\section{Creep-rupture}

Creep data are given, but no comparable air data are given due to lack of availability. ${ }^{2}$ 


\section{Tensile and impact tests}

Tensile and impact data are given, although no comparisons are made with air data due to lack of availability. ${ }^{2}$

\section{S-816}

\section{Creep-rupture}

The creep-rupture life was slightly longer in air than in Grade A helium, and the minimum creep rate was higher in air. ${ }^{19}$ There was very little effect of environment on elongation. The ratio of notched rupture life to unnotched rupture life was greater in air than in helium.

\section{DISCUSSION}

\section{Corrosion Tests}

A review of the preceding information on the corrosion of the various superalloys in helium atmospheres reveals that the surface coating in most instances consists of chromium oxide plus, in some cases, the oxide of some of the alloying constituents. In the studies where analyses were made of the intergranular corrosion product, aluminum and titanium were found to be involved. In the few cases where chromium was not the dominant species in the surface scale, aluminum and/or titanium were found to be present in large amounts. Several workers have concluded that the presence of aluminum and titanium are detrimental to the corrosion resistance of superalloys in helium. ${ }^{5,7,12,14}$ Huddle $^{7}$ suggests that carbon control by the use of niobium is more beneficial than control by the use of titanium.

With some exceptions, the oxide layer is considered to be continuous. The continuous nature of the film is indicated by the following:

1. Where quantitative data have been obtained, parabolic rate curves have been found. ${ }^{8,12}$

2. The carburization rate decreases upon formation of an oxide film. ${ }^{11,20}$

3. Catalysis of the decomposition of $\mathrm{CO}$ (the Boudouard reaction) decreases upon formation of the film. ${ }^{17}$

4. An increase in oxidation was found after spalling occurred because of thermal cycling. ${ }^{20}$

5. Intergranular oxidation in one instance was found only in strained specimens, probably due to oxidation in growing cracks. ${ }^{5}$

Under very high purity helium or low pressures of $\mathrm{CO}$ or $\mathrm{CO}+\mathrm{H}_{2}$, weight losses have occurred because of the evaporation of chromium from the surface.$^{24,25,29}$.n these cases, a continuous oxide scale is not formed and the conditions are, thermodynamically at least, analogous to vacuum conditions.

Carburization occurred in most cases, although in a few instances decarburization was

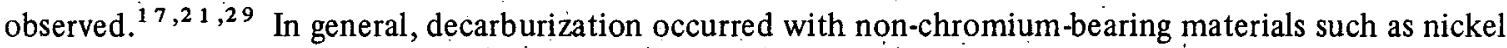
and Monel, or under highly reducing atmospheres of $\mathrm{H}_{2}$ or $\mathrm{CO}+\mathrm{H}_{2}$. In one case, severe decarburization occurred in helium with $500 \mathrm{ppm} \mathrm{O}_{2}{ }^{21}{ }^{21}$ However, analyses of the gas showed a loss of $\mathrm{H}_{2} \mathrm{O}$ between the gas inlet and outlet.

Oxidation reactions for the alloying constituents are the result of the reactions:

$$
\mathrm{M}+\mathrm{CO}_{2} \leftrightarrows \mathrm{MO}+\mathrm{CO} \quad \mathrm{K}_{1}=\frac{\mathrm{P}_{\mathrm{CO}}}{\mathrm{P}_{\mathrm{CO}_{2}}}
$$


and

$$
\mathrm{M}+\mathrm{H}_{2} \mathrm{O} \leftrightarrows \mathrm{MO}+\mathrm{H}_{2} \quad \mathrm{~K}_{2}=\frac{\mathrm{P}_{\mathrm{H}_{2}}}{\mathrm{P}_{\mathrm{H}_{2} \mathrm{O}}}
$$

Reaction 1 is the sum of the reactions:

$$
\mathrm{CO}_{2} \leftrightarrows \mathrm{CO}+1 / 2 \mathrm{O}_{2}
$$

$$
\mathrm{K}_{3}=\frac{\left(\mathrm{P}_{\mathrm{CO}}\right)\left(\mathrm{P}_{\mathrm{O}_{2}}\right)^{\frac{1}{2}}}{\left(\mathrm{P}_{\mathrm{CO}_{2}}\right)}
$$

and

$$
\mathrm{M}+1 / 2 \mathrm{O}_{2} \leftrightarrows \mathrm{MO}
$$

$$
\mathrm{K}_{4}=\frac{1}{\left(\mathrm{P}_{\mathrm{O}_{2}}\right)^{1 / 2}}
$$

Reaction 2 is the sum of the reactions:

$$
\mathrm{H}_{2} \mathrm{O} \leftrightarrows \mathrm{H}_{2}+1 / 2 \mathrm{O}_{2}
$$

$$
\mathrm{K}_{5}=\frac{\left(\mathrm{P}_{\mathrm{H}_{2}}\right)\left(\mathrm{P}_{\mathrm{O}_{2}}\right)^{1 / 2}}{\left(\mathrm{P}_{\mathrm{H}_{2} \mathrm{O}}\right)}
$$

and

$$
\mathrm{M}+1 / 2 \mathrm{O}_{2} \leftrightarrows \mathrm{MO}
$$

$$
\mathrm{K}_{4}=\frac{1}{\left(\mathrm{P}_{\mathrm{O}_{2}}\right)^{1 / 2}}
$$

These reactions suggest that thermodynamically the pressure of the reacting gases is not as important as the ratios $\mathrm{P}_{\mathrm{CO}} / \mathrm{P}_{\mathrm{CO}_{2}}$ and $\mathrm{P}_{\mathrm{H}_{2}} / \mathrm{P}_{\mathrm{H}_{2} \mathrm{O}}$, the oxidation potentials. As the oxidation potential increases, the tendency for alloy constituents to oxidize decreases. This is shown in Fig. 1, which gives curves for the free energy of formation of various oxides as a function of temperature. Superimposed on these curves are similar values for reactions 3 and 5 at various oxidation potentials. For values of $\mathrm{H}_{2} / \mathrm{H}_{2} \mathrm{O}$ less than or equal to $1000, \mathrm{Cr}_{2} \mathrm{O}_{3}$ and $\mathrm{Nb}_{2} \mathrm{O}_{5}$ are stable below $1200^{\circ} \mathrm{C}, \mathrm{NbO}_{2}$ is stable below $1390^{\circ} \mathrm{C}$, and $\mathrm{MnO}$ is stable below about $1500^{\circ} \mathrm{C}$. The oxides of silicon, titanium, and aluminum are stable at all temperatures. For values of $\mathrm{CO} / \mathrm{CO}_{2}$ less than or equal to 1000 , the oxides of chromium, niobium, manganese, silicon, titanium, and aluminum are stable. From this figure it can be seen that if the oxidation potential $\mathrm{H}_{2} / \mathrm{H}_{2} \mathrm{O}$ is increased above 1000 , the temperature of stability of chromium oxide, $\mathrm{Cr}_{2} \mathrm{O}_{3}$, will decrease and this will prevent the formation of a protective oxide coating. This then increases the potential for more rapid internal oxidation and intergranular oxidation of other alloying constituents. This process may have strongly negative consequences on the mechanical properties of the alloy.

Similar curves for carbide formation are given in Fig. 2. Also included in this figure are curves for the following reactions:

$$
\mathrm{C}+\mathrm{CO}_{2} \leftrightarrows 2 \mathrm{CO}
$$

$$
\mathrm{K}_{6}=\frac{\left(\mathrm{P}_{\mathrm{CO}}\right)^{2}}{\left(\mathrm{P}_{\mathrm{CO}_{2}}\right)}
$$




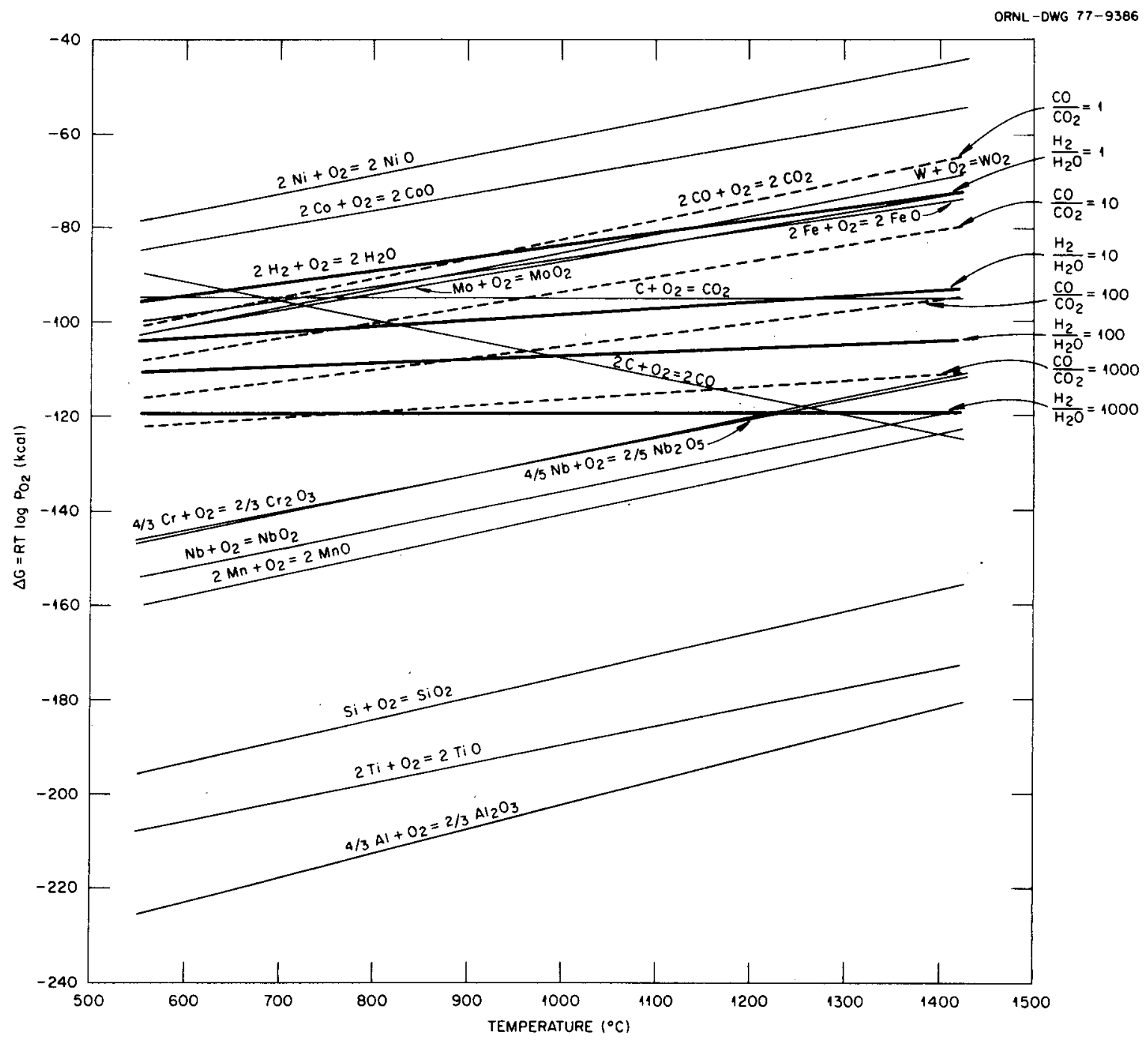

Fig. 1. Standard free-energy diagram for oxides. Source: F. D. Richardson, Physical Chemistry of Melts in Metallurgy, vol. 2, p. 333, Academic Press, New York, 1974.

and
$\mathrm{C}+2 \mathrm{H}_{2} \leftrightarrows \mathrm{CH}_{4}$
$\mathrm{K}_{7}=\frac{\left(\mathrm{P}_{\mathrm{CH}_{4}}\right)}{\left(\mathrm{P}_{\mathrm{H}_{2}}\right)^{2}}$.

From these equations and the resulting equilibrium constants, the carburization potentials are defined as $\left(\mathrm{P}_{\mathrm{CO}}\right)^{2} /\left(\mathrm{P}_{\mathrm{CO}_{2}}\right)$ and $\left(\mathrm{P}_{\mathrm{CH}_{4}}\right) /\left(\mathrm{P}_{\mathrm{H}_{2}}\right)^{2}$. In Fig. 2, curves for reactions 6 and 7 are drawn for different values of the carburization potential. From this figure it is. seen that methane decomposition is favored at carburization potentials greater than or equal to 0.01 , at all temperatures between 600 and $1400^{\circ} \mathrm{C}$, to form carbides with all of the alloying constituents shown. Only with very low values of $\left(\mathrm{P}_{\mathrm{CO}}\right)^{2} / \mathrm{P}_{\mathrm{CO}}($ less than 1) will any appreciable decarburization take place below $1200^{\circ} \mathrm{C}$. Since this implies high $\mathrm{P}_{\mathrm{CO}_{2}}$ or high 


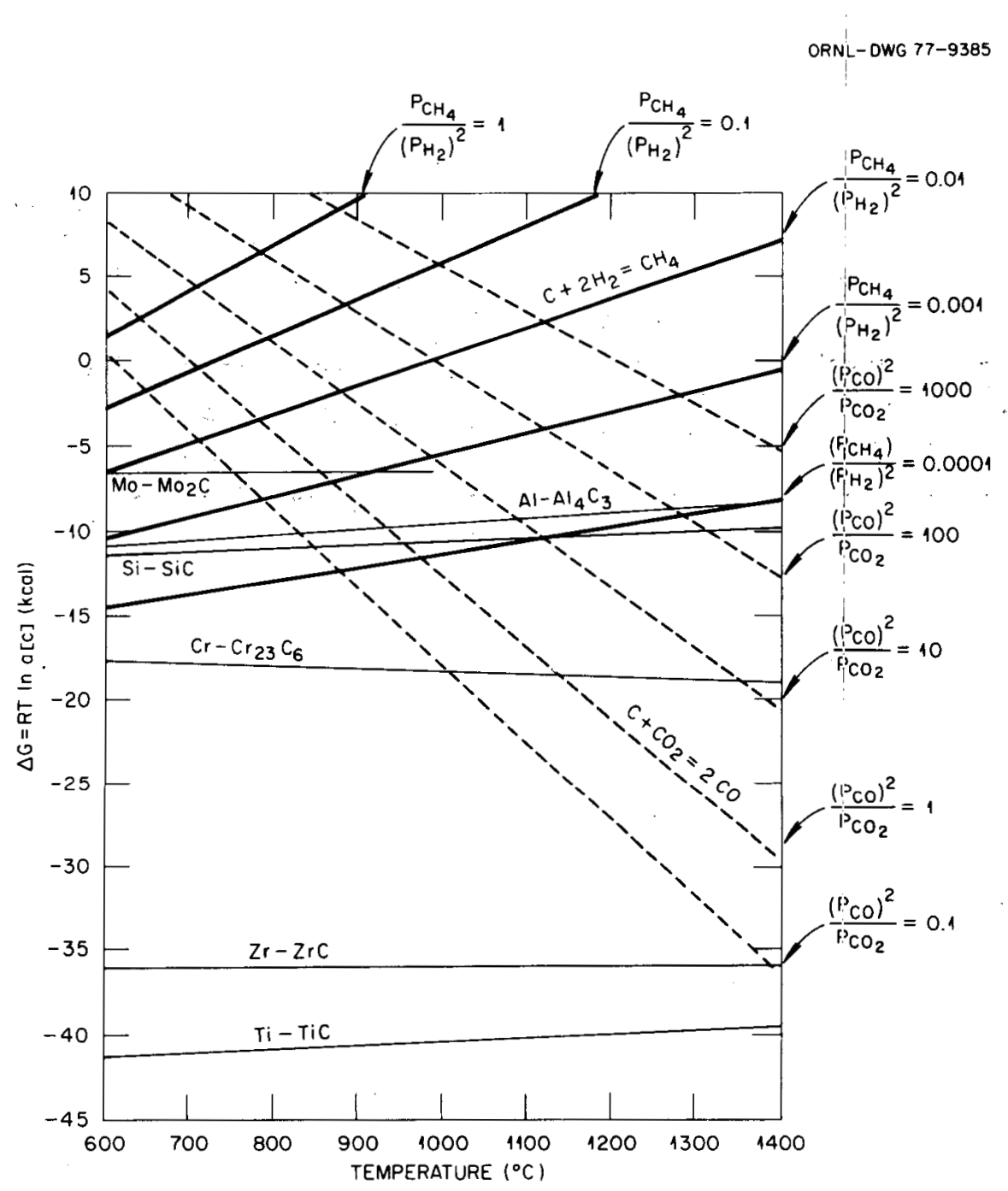

Fig. 2. Pure carbide free-energy diagram. Source: F. D. Richardson, Physical Chemistry of Melts in Metallurgy, vol. 2, p. 344, Academic Press, New York, 1974.

$\mathrm{P}_{\mathrm{H}_{2}}$, the previously mentioned cases of decarburization can be explained. Hoivever, when $\mathrm{P}_{\mathrm{CO}_{2}}$ is high, Fig. 1 then shows that oxidation of chromium is favored; thus the use of $\mathrm{CO}_{2}$ to inhibit decarburization will only serve to promote oxidation of alloying constituents.

As the oxidation potential of the gas increases, the tendency for oxidation of the alloying constituents decreases, and one would expect that this would produce desirable effects on the alloy. However, the evidence indicates that as the oxide layer becomes discontinuous or nonexisten, internal oxidation and/or evaporation of alloying constituents - notably chromium and manganese - becomes important. Evaporation from the surface can also produce undesirable side effects, which must be studied in detail before proper design values can be ascribed to any given alloy: It would appear that some oxygen in the system is called for, to minimize the undesirable effects of atmosphere.

Internal oxidation appears to be related to chromium removal. ${ }^{15}$ There is also a relationship between the depth of internal oxidation $\mathrm{D}$ and the chromium and titanium content of the alloy. An empirical relationship was found ${ }^{15}$ and it is represented by the equation: 
$\mathrm{D}=14.8+4.72(\mathrm{wt} \% \mathrm{Cr})+52.5(\mathrm{wt} \% \mathrm{Ti})$

where $\mathrm{D}$ is in $\mu \mathrm{m}$.

\section{Weldments}

Only one reference was found which addressed the problem of the effects of helium impurities on weldments. ${ }^{20}$ In flowing helium $\left(\mathrm{He}+0.5 \% \mathrm{O}_{2}+0.54 \% \mathrm{~N}_{2}\right)$ at $1200^{\circ} \mathrm{C}$ for seven days, Hastelloy $\mathrm{X}-280 /$ Hastelloy X-280 weldments showed oxidation resistance equivalent to the parent metal. For Hastelloy X-280/Haynes 25 weldments, the oxidation resistance of the couple depends on the oxidation resistance of the Haynes 25 .

\section{Surface Treatments}

Sakakibara, Banno, and Sekino ${ }^{15}$ found that preoxidizing the surface of the alloys, or coating the surface with aluminum by calorizing, improved the corrosion resistance. Both the weight gain and the amount of internal oxidation were decreased.

\section{Creep-Rupture Tests}

A summary of the creep data reported for the various alloys is given in Tables 4-7. Analysis of these data for definitive answers on the effects of helium on creep properties is complicated by several factors:

1. differences in test atmosphere,

2. differences in test parameters: stress, temperature, and time,

3. lack of comparison with air data under similar test conditions,

4. variations in alloy composition and heat treatment,

5. wide ranges of alloy content among the various alloys.

Nevertheless, some generalizations are possible. A number of workers have also proposed mechanisms for specific cases. An attempt will be made in this section to bring together these various proposals and develop a generalized mechanism to account for the effect of a helium atmosphere on the creep rupture properties of superalloys.

The data of Tables 4-7 can be summarized further by comparing, wherever possible, the creep properties - creep rate, time to rupture, and rupture ductility - in helium with respect to those in air. This is done in Table 8. In addition to the information given in Tables $4-7$, other qualitative statements are included in Table 8, although substantiating data cannot be presented because of the format of Tables 4-7. There are suggestions ${ }^{5,9}$ that Inconel 617 and Inconel 625 show a strengthening effect (lower strain rates) in helium as compared to air at 750 and $850^{\circ} \mathrm{C}$. However, for Inconel 617 the effect of environment depends on the duration of the test. Nickel shows a variable effect of oxygen content on rupture life. ${ }^{30}$ As the oxygen content increases to about $10^{-4}$ torr, at $600^{\circ} \mathrm{C}$; the rupture life decreases; above $10^{-4}$ torr no further decrease is noted. Similar results were obtained at $510^{\circ} \mathrm{C}$. For Incoloy 800 , Bates et al. ${ }^{10}$ concluded that while the overall life of the alloy at $650^{\circ} \mathrm{C}$ was longer in helium, the elongation at fracture was less. This is at variance with the information given in Table 8. 'Tables 4-7 suggest that this may be true at lower stresses; but at higher stresses $\mathrm{t}_{\mathrm{r}}(\mathrm{He}) / \mathrm{t}_{\mathrm{r}}$ (Air) $<1$.

From Table 8, it appears that in most cases the time to rupture is longer in air than in helium. Also, the rupture ductility is greater in most cases in helium than in air. However, the creep rate data are not as clear-cut: in some cases the creep rate is higher in helium, and in others it is higher in air. 
Table 4. Summary of creep data for Incoloy 800

\begin{tabular}{|c|c|c|c|c|c|c|c|c|c|c|c|c|c|c|c|c|}
\hline \multirow{2}{*}{ Alloy } & \multirow{2}{*}{$\begin{array}{c}\text { Temperature } \\
\left.{ }^{\circ} \mathrm{C}\right)\end{array}$} & \multirow{2}{*}{ Atmosphere } & \multicolumn{2}{|c|}{ Stress } & \multirow{2}{*}{$\begin{array}{c}\text { Creep rate } \\
\left(\mathrm{hr}^{-1}\right)\end{array}$} & \multirow{2}{*}{$\begin{array}{l}\text { Time to } \\
\text { rupture } \\
\text { (hr) }\end{array}$} & \multirow{2}{*}{$\begin{array}{l}\text { Elongation } \\
\text { (\%) }\end{array}$} & \multirow{2}{*}{$\begin{array}{c}\text { Reduction } \\
\text { in area } \\
(\%)\end{array}$} & \multicolumn{3}{|c|}{ Time to strain (hr) } & \multirow{2}{*}{$\begin{array}{l}\text { Time to } \\
\text { tertiary } \\
\text { creep } \\
\text { (hr) }\end{array}$} & \multirow{2}{*}{$\begin{array}{l}\text { Time } \\
\text { of } \\
\text { test } \\
\text { (hr) }\end{array}$} & \multirow{2}{*}{$\begin{array}{l}\text { Final } \\
\text { strain } \\
\text { (\%). }\end{array}$} & \multirow{2}{*}{ Refierence } & \multirow{2}{*}{ Remarks } \\
\hline & & & (psi) & $\left(\mathrm{N} / \mathrm{mm}^{2}\right)$ & & & & & $5 \%$ & $1.0 \%$ & $2.0 \%$ & & & & & \\
\hline \multirow[t]{39}{*}{ Incoloy 800} & 650 & Pure $\mathrm{He}^{a}$ & 25,000 & 172 & $3.5 \times 10^{-4}$ & 1270 & 45 & & & 10 & 30 & & & & 4 & \\
\hline & 650 & Pure $\mathrm{He}^{a}$ & 25,000 & 172 & $5.0 \times 10^{-4}$ & 500 & 38 & & & & & & & & 4 & \\
\hline & 650 & Impure $\mathrm{He}^{b}$ & 25,000 & 172 & $1.8 \times 10^{-5}$ & 1460 & 7 & & 250 & 480 & 820 & & & & 4 & \\
\hline & 650 & Impure $\mathrm{He}^{b}$ & 25,000 & 172 & $2.0 \times 10^{-5}$ & 980 & 8 & & 210 & 400 & 620 & & & & 4 & \\
\hline & 650 & Air & 25,000 & 172 & $8.0 \times 10^{-6}$ & 2300 & 8 & & 260 & 800 & 1400 & & & & 4 & \\
\hline & 650 & Air & 25,000 & 172 & $9.0 \times 10^{-6}$ & 1900 & 20 & & 80 & 550 & 1300 & & & & 4 & \\
\hline & 650 & Pure $\mathrm{He}^{a}$ & 22,500 & 155 & $2.0 \times 10^{-4}$ & 960 & 48 & & & 2 & 25 & & & & 4 & \\
\hline & 650 & Pure $\mathrm{He}^{a}$ & 22,500 & 155 & $2.6 \times 10^{-5}$ & 1790 & 10 & & 190 & 380 & 760 & & & & 4 & \\
\hline & 650 & Impure $\mathrm{He}^{b}$ & 22,500 & 155 & $3.0 \times 10^{-5}$ & 1080 & 14 & & 70 & 235 & 465 & & & & 4 & \\
\hline & 650 & Impure $\mathrm{He}^{b}$ & 22,500 & 155 & $1.6 \times 10^{-5}$ & 1990 & 18 & & 200 & 515 & 1160 & & & & 4 & \\
\hline & 650 & Air & 22,500 & 155 & $3.5 \times 10^{-5}$ & 4250 & 22 & & 25 & 80 & 265 & & & & 4 & \\
\hline & 650 & Air & 22,500 & 155 & $3.3 \times 10^{-6}$ & 4460 & 4.6 & & 1240 & 2320 & 3710 & & & & 4 & \\
\hline & 650 & Air & 22,500 & 155 & $1.6 \times 10^{-6}$ & 6370 & 5.0 & & 2375 & 3800 & 5000 & & & & 4 & \\
\hline & 650 & Air & 22,500 & 155 & $3.4 \times 10^{-6}$ & 5420 & 5.8 & & 500 & 2000 & 3950 & & & & 4 & \\
\hline & 650 & Pure $\mathrm{He}^{a}$ & 20,000 & 138 & $2.0 \times 10^{-6}$ & $>900$ & & & & & & & & & 4 & \\
\hline & 650 & Impure $\mathrm{He}^{b}$ & 20,000 & 138 & $2.6 \times 10^{-6}$ & 4970 & 8 & & 1560 & 2340 & 3200 & & & & 4 & \\
\hline & 650 & Impure $\mathrm{He}^{b}$ & 20,000 & 138 & $5.0 \times 10^{-6}$ & 3510 & 12 & & 800 & 1300 & 2150 & & & & 4 & \\
\hline & 650 & $\mathrm{Air}$ & 20,000 & 138 & $1.4 \times 10^{-6}$ & 7660 & 10 & & 2400 & 3800 & 4600 & & & & 4 & \\
\hline & 650 & Air & 20,000 & 138 & $2.0 \times 10^{-6}$ & $>3580$ & & & 1250 & 2500 & & & & & 4 & \\
\hline & 650 & Pure $\mathrm{He}^{a}$ & 18,000 & 125 & $1.5 \times 10^{-6}$ & $>5870$ & & & & & & & & & 4 & \\
\hline & 649 & $\mathrm{He}^{c}$ & 36,000 & 248 & $6.7 \times 10^{-4}$ & 70.8 & 37 & 49 & & & & 22 & & & 15 & \\
\hline & 649 & $\mathrm{He}^{c}$ & 36,000 & 248 & $5.1 \times 10^{-4}$ & 79.5 & 47 & 47 & & & & 20 & & & 15 & \\
\hline & 649 & $\mathrm{He}^{c}$ & 36,000 & 248 & $4.2 \times 10^{-4}$ & 55.0 & 46 & 50 & & & & 18 & & & 15 & \\
\hline & 649 & $\mathrm{He}^{c}$ & 26,000 & 179 & $2.0 \times 10^{-5}$ & 1195 & 18 & 40 & & & & 475 & & & 15 & \\
\hline & 649 & $\mathrm{He}^{c}$ & 21,000 & 145 & $5.0 \times 10^{-6}$ & 3785 & 18 & 38 & & & & 950 & & & 15 & \\
\hline & 760 & $\mathrm{He}^{c}$ & 12,000 & 82.7 & $1.8 \times 10^{-3}$ & 149 & 60 & & & & & 70 & & & 15 & \\
\hline & 760 & $\mathrm{He}^{c}$ & 12,000 & 82.7 & $1.3 \times 10^{-3}$ & 122 & 65 & 64 & & & & 45 & & & 15 & \\
\hline & 760 & $\mathrm{He}^{c}$ & 12,000 & 82.7 & $2.2 \times 10^{-3}$ & 129 & 69 & 60 & & & & 45 & & & 15 & \\
\hline & 760 & $\mathrm{He}^{c}$ & 12,000 & 82.7 & $2.3 \times 10^{-4}$ & 248 & 49 & 55 & & & & 80 & & & 15 & \\
\hline & 760 & $\mathrm{He}^{c}$ & 12,000 & 82.7 & $1.1 \times 10^{-4}$ & 310 & 39 & 51 & & & & 140 & & & 15 & \\
\hline & 871 & $\mathrm{He}^{c}$ & 4,000 & 27.6 & $1.43 \times 10^{-4}$ & 661 & 23 & 31 & & & & 200 & & & .15 & \\
\hline & 750 & $\mathrm{He}^{d}$ & & & & & & & & & & & 5800 & 2.0 & 10 & $\frac{\mathrm{oHc}}{\mathrm{\sigma a \textrm {ai }}}=0.79$ \\
\hline & 750 & $\mathrm{He}^{d}$ & & & & & & & & & & & 11000 & 3.0 & 10 & $\frac{\sigma \mathrm{He}}{\sigma \mathrm{air}}=0.76$ \\
\hline & 750 & $\mathrm{He}^{d}$ & & & & & & & & & & & 1000 & 5.0 & 10 & $\frac{\mathrm{oHe}}{\text { odir }}=1.04$ \\
\hline & 750 & $\mathrm{He}^{d}$ & & & & & . & & & & & & 4300 & 0.2 & 10 & $\frac{o H \bar{c}}{\text { odir }}=1.00$ \\
\hline & 750 & $\mathrm{He}^{d}$ & & & & & & & & & & & 1200 & $0.5^{\circ}$ & 10 & $\frac{\overline{\frac{\sigma \mathrm{He}}{\sigma \mathrm{c}}}}{\sigma \mathrm{air}}=1.20$ \\
\hline & 750 & $\mathrm{He}^{d}$ & & & & & & & & & & & 4000 & Rupture & 10 & $\frac{\sigma \mathrm{He}}{\sigma \mathrm{air}}=1.14$ \\
\hline & 650 & $\mathrm{He}^{d}$ & & & & & & & & & & & 1500 & Rupture & 10 & $\frac{\sigma \mathrm{He}}{\sigma \mathrm{air}}=1.11$ \\
\hline & 800 & $\mathrm{He}^{d}$ & & & & & & & & & & & 3000 & 5.0 & 10 & $\frac{\sigma \mathrm{He}}{\sigma \mathrm{air}}=1.19$ \\
\hline
\end{tabular}

$a_{5}-680 \mathrm{ppm} \mathrm{H}_{2}, 10-100 \mathrm{ppm} \mathrm{CO}, 4-160 \mathrm{ppm} \mathrm{H}_{2} \mathrm{O}, 5-20 \mathrm{ppm} \mathrm{CH}_{4}, 1-20 \mathrm{ppm} \mathrm{O}_{2}, 4-200 \mathrm{ppm} \mathrm{N}$.

$b_{1000-1600 \mathrm{ppm} \mathrm{H}}, 10-1100 \mathrm{ppm} \mathrm{CO}, 200-700 \mathrm{ppm} \mathrm{H}_{2} \mathrm{O}, 5-20 \mathrm{ppm} \mathrm{CH}_{4}, 10-50 \mathrm{ppm}_{2}, 70-200 \mathrm{ppm} \mathrm{N}$.

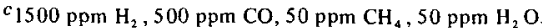

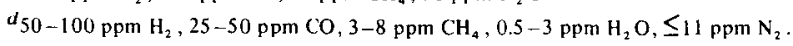


Table 5. Summary of creep data for Inconel alloys

\begin{tabular}{|c|c|c|c|c|c|c|c|c|c|c|c|c|c|}
\hline \multirow{2}{*}{ Alloy } & \multirow{2}{*}{$\begin{array}{c}\text { Temperature } \\
\left({ }^{\circ} \mathrm{C}\right)\end{array}$} & \multirow{2}{*}{\multicolumn{2}{|c|}{ Atmosphere }} & \multicolumn{2}{|c|}{ Stress } & \multirow{2}{*}{$\begin{array}{c}\text { Creep rate } \\
\left(\mathrm{hr}^{-1}\right)\end{array}$} & \multirow{2}{*}{$\begin{array}{l}\text { Time to } \\
\text { rupture } \\
\text { (hr) }\end{array}$} & \multirow{2}{*}{$\begin{array}{c}\text { Elongation } \\
\text { (\%) }\end{array}$} & \multirow{2}{*}{$\begin{array}{c}\text { Reduction } \\
\text { in area } \\
(\%)\end{array}$} & \multirow{2}{*}{$\begin{array}{c}\text { Time } \\
\text { of } \\
\text { test } \\
(\mathrm{hr})\end{array}$} & \multirow{2}{*}{$\begin{array}{c}\text { Final } \\
\text { strain } \\
(\%)\end{array}$} & \multirow{2}{*}{ Reference } & \multirow{2}{*}{ Remarks } \\
\hline & & & & $\overline{(\mathrm{psi})}$ & $\left(\mathrm{N} / \mathrm{mm}^{2}\right)$ & & & & & & & & \\
\hline \multirow{8}{*}{ Inconel $\mathrm{X}$} & 704 & \multicolumn{2}{|c|}{$\mathrm{He}+89 \mathrm{ppm}$ impurities } & 50,000 & 345 & & 350 & 1.6 & 3.0 & & & 17 & \\
\hline & 704 & \multicolumn{2}{|c|}{$\mathrm{He}+89 \mathrm{ppm}$ impurities } & 45,000 & 310 & & 650 & 1.8 & 2.1 & & & 17 & \\
\hline & 704 & \multirow{2}{*}{\multicolumn{2}{|c|}{$\begin{array}{l}\mathrm{He}+89 \mathrm{ppm} \text { impurities } \\
\mathrm{He}+89 \mathrm{ppm} \text { impurities }\end{array}$}} & 38,000 & 262 & & 1600 & 1.5 & 4.0 & & & 17 & \\
\hline & 704 & & & 35,000 & 241 & & 2700 & 2.0 & 1.0 & & & 17 & \\
\hline & 816 & \multicolumn{2}{|c|}{ Air } & 25,000 & 172 & $3.4 \times 10^{-5}$ & 208.3 & 4.9 & 7.8 & & & 18 & unnotched bar \\
\hline & 816 & \multicolumn{2}{|c|}{ Grade A He } & 25,000 & 172 & $3.8 \times 10^{-5}$ & 185.4 & 8.7 & 12.0 & & & 18 & unnotched bar \\
\hline & 816 & $\mathrm{~A} \mathrm{i}$ & & 30,000 & 207 & 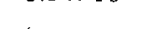 & 123.1 & & & & & 18 & notched bar \\
\hline & 816 & \multicolumn{2}{|c|}{ Grade A Hè } & 30,000 & 207 & & 41.3 & & & & & 18 & notched bar \\
\hline \multirow[t]{8}{*}{ Inconel 617} & 800 & \multicolumn{2}{|c|}{ Controlled-impurity $\mathrm{He}^{a}$} & 4,400 & 31 & 0 & & & & & & 2 & \\
\hline & 900 & .. & & 1,900 & 13 & $7.7 \times 10^{-7}$ & & & & & & 2 & \\
\hline & 800 & $\dot{A}$ & $\therefore$ & & & $3 \times 10^{-5}$ & & & & & & 2 & Literature values \\
\hline & 900 & $\mathrm{Ai}$ & $\because$ & & & $3 \times 10^{-6}$ & & & & & & 2 & Literature values \\
\hline & 850 & $\mathrm{He}$ & $:$ & 6,140 & 42.3 & & & & & 2000 & 1.7 & 5 & \\
\hline & 850 & $\mathrm{He}$ & $\therefore$ & 5,280 & 36.4 & & & & & 2000 & 0.11 & 5 & \\
\hline & 900 & $\mathrm{He}$ & $\because$ & 3,030 & 20.9 & & & & & 3000 & 5.29 & 5 & \\
\hline & 850 & $\ddot{\mathrm{A}} \mathrm{i}$ & $\because$ & 5,280 & 36.4 & . & & & & 2000 & 0.18 & 5 & \\
\hline \multirow[t]{23}{*}{ Inconel 625} & 750 & $\mathrm{He}$ & $\because \quad \because$ & 17,000 & 117 & & & & & 2260 & 45 & 5 & \\
\hline & 750 & $\mathrm{He}$ & $\therefore \therefore a$ & 17,000 & 117 & & & & & 2260 & 30 & 5 & \\
\hline & 750 & $\mathrm{He}$ & 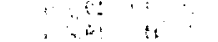 & 17,000 & 117 & & 2260 & 82 & & & & 5 & \\
\hline & 750 & $\mathrm{He}$ & 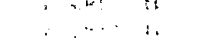 & 15,200 & 105 . & & & 02 & 2500 & & 10.7 & 5 & \\
\hline & 750 & $\mathrm{He}$ & $\therefore$ & 15,200 & 105 & & & & & 3500 & 28 & 5 & \\
\hline & $750^{\circ}$ & $\mathrm{He}$ & & 15,200 & 105 & & & & & 3500 & 36 & 5 & \\
\hline & 750 & $\mathrm{He}$ & $:$ & 13,600 & 94 & & & & & 2500 & 4.2 & 5 & \\
\hline & 750 & $\mathrm{He}$ & & 13,600 & 94 & & & & & 4500 & 27 & 5 & \\
\hline & 750 & $\mathrm{He}$ & & 13,600 & 94 & & 5265 & 135 & & & & 5 & \\
\hline & 750 & $\mathrm{Ai}$ & & 14,500 & 100 & & & & & 2000 & 6.0 & 5 & \\
\hline & 750 & $\mathrm{Ai}$ & $\therefore$ & 14,500 & 100 & & 4522 & 109 & & & & 5 & \\
\hline & 750 & $\mathrm{Ai}$ & .. & 14,500 & 100 & & 4000 & 92 & & & & 5 & \\
\hline & 750 & $\mathrm{Ai}$ & & 13,600 & 94 & & 3990 & 126 & & & & 5 & \\
\hline & 750 & $\mathrm{Ai}$ & $\because$ & 13,600 & 94 & & 4750 & 103 & & & & 5 & \\
\hline & 750. & $\mathrm{Ai}$ & & 13,600 & 94 & & & & & 4750 & 27 & 5 & \\
\hline & 850 & $\mathrm{He}$ & 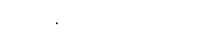 & 7,200 & 50 & & 7755 & 4.5 & & & & 5 & \\
\hline & 850 & $\mathrm{He}$ & & 7,000 & 48.5 & & & & & 5000 & 1.9 & 5 & \\
\hline & 850 & $\mathrm{Ai}$ & & 7,300 & 50.6 & & 8090 & 32 & & & & 5 & \\
\hline & 850 & $\mathrm{Ai}$ & & 7,300 & 50.1 & & 8070 & 18 & & & & 5 & \\
\hline & 850 & $\mathrm{Ai}$ & & 7,000 & 48.5 & & & & & 8000 & 6.1 & 5 & \\
\hline & 850 & $\mathrm{Ai}$ & & 7,100 & 48.9 & & 10240 & 18 & & & & 5 & \\
\hline & 850 & $\mathrm{Ai}$ & & 6,800 & 47.1 & & 10480 & 10 & & & & 5 & \\
\hline & 850 & $\mathrm{Ai}$ & & 6,800 & 47.1 & & 9072 & 8.3 & & & & 5 & \\
\hline
\end{tabular}

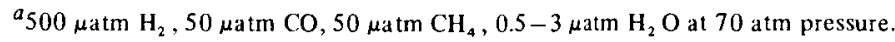

$b_{500 \mu \mathrm{atm} \mathrm{H}}, 50 \mu \mathrm{atm} \mathrm{CO}, 1.5 \mu \mathrm{atm} \mathrm{H}_{2} \mathrm{O} .50 \mu \mathrm{atm \textrm {CH } _ { 4 }}, \leq 11 \mu \mathrm{atm} \mathrm{N} \mathrm{N}_{2}$ at $1.8 \mathrm{~atm}$ pressure. 
Table 6. Summary of creep data for Hastelloy alloys

\begin{tabular}{|c|c|c|c|c|c|c|c|c|c|c|c|c|}
\hline \multirow{2}{*}{ Alloy } & \multirow{2}{*}{$\begin{array}{c}\text { Temperature } \\
\left({ }^{\circ} \mathrm{C}\right)\end{array}$} & \multirow{2}{*}{ Atmosphere } & \multicolumn{2}{|c|}{ Stress } & \multirow{2}{*}{$\begin{array}{c}\text { Creep rate } \\
\left(h_{r^{-1}}\right)\end{array}$} & \multirow{2}{*}{$\begin{array}{l}\text { Time to } \\
\text { rupture } \\
\text { (hr) }\end{array}$} & \multirow{2}{*}{$\begin{array}{l}\text { Elongation } \\
\qquad(\%)\end{array}$} & \multirow{2}{*}{$\begin{array}{c}\text { Reduction } \\
\text { in aread } \\
(\%)\end{array}$} & \multirow{2}{*}{$\begin{array}{l}\text { Time to } \\
\text { strain (hr) } \\
2.0 \%\end{array}$} & \multirow{2}{*}{$\begin{array}{l}\text { Time to } \\
\text { tertiary } \\
\text { creep } \\
\text { (hr) }\end{array}$} & \multirow{2}{*}{$\begin{array}{l}\text { Time } \\
\text { of } \\
\text { test } \\
\text { (ht) }\end{array}$} & \multirow{2}{*}{ Reference } \\
\hline & & & (psi) & $\left(\mathrm{N} / \mathrm{mm}^{2}\right)$ & & & & & & & & \\
\hline \multirow[t]{7}{*}{ Hastelloy $\mathrm{C}$} & 871 & Air & 8,000 & 55.2 & & 142 & & & & & & 21 \\
\hline & 871 & Air & 8,000 & 55.2 & & 130 & & & & & & 21 \\
\hline & 871 & Air & 7,000 & 48.3 & & 315 & & & & & & 21 \\
\hline & 871 & Air & 5,000 & 34.5 & & 1755 & & & & & & 21 \\
\hline & 871 & Air & 5.000 & 34.5 & & 2084 & & & & & & 21 \\
\hline & .871 & Air & 5,000 & 34.5 & & 2255 & & & & & & 21 \\
\hline & 871 & $\mathrm{He}^{b}$ & 5,000 & 34.5 & & 1746 & & & & & & 21 \\
\hline \multirow[t]{11}{*}{ Hastelloy $x$} & 649 & $\mathrm{He}^{\mathrm{c}}$ & 25,000 & 172 & $1.7 \times 10^{-5}$ & 6466 & 34.9 & & 850 & 3950 & & 28 \\
\hline & 704 & Air & 20,000 & 138 & $1.2 \times 10^{-5}$ & 4504 & 18.3 & & 297 & 1950 & & 27 \\
\hline & 704 & $\mathrm{He}^{c}$ & 20,000 & 138 & $1.1 \times 10^{-5}$ & 4588 & 23.0 & & 500 & 2000 & & 28 \\
\hline & 704 & $\mathrm{He}^{c}$ & 20,000 & 138 & $1.7 \times 10^{-5}$ & 4045 & 21.4 & & 344 & 1950 & & 28 \\
\hline & 704 & $\mathrm{H} \geq^{\mathrm{C}}$ & 25,000 & 172 & $1.4 \times 10^{-4}$ & 1007 & 35.4 & & 104 & 510 & & 28 \\
\hline & 760 & $\mathrm{He}^{\mathrm{c}}$ & 15,000 & 103 & $1.2 \times 10^{-3}$ & 2690 & 18.7 & & 1110 & 1480 & & 28 \\
\hline & 760 & Air & 20,000 & 138 & $4.6 \times 10^{-4}$ & 297 & $\$ 2.4$ & & 35 & 113 & & 28 \\
\hline & 760 & $\mathrm{He}^{\mathrm{c}}$ & 20,000 & $\begin{array}{l}138 \\
138\end{array}$ & $4.0 \times 10^{-4}$ & 305 & 38.9 & & 30 & 142 & & 28 \\
\hline & 760 & $\mathrm{He}^{c}$ & 22,000 & 152 & $1.2 \times 10^{-3}$ & 159 & 57.5 & & 15 & 44 & & 28 \\
\hline & 816 & Air & 10,000 & 69 & $21 \times 10^{-5}$ & 3453 & 18.8 & & $\sim 940$ & 650 & & 26 \\
\hline & 871 & $\mathrm{He}^{\mathrm{c}}$ & 9,000 & 62 & $9.3 \times 10^{-5}$ & 554 & 34.8 & & 197 & 205 & & 28 \\
\hline \multirow[t]{7}{*}{ Hastelloy $C$} & 871 & $\mathrm{He}^{b}$ & 5,000 & 34.5 & & 1748 & & & & & & 21 \\
\hline & 871. & $\mathrm{He}^{b}$ & 5,000 & 34.5 & & 1713 & & & & & & 21 \\
\hline & 871 & $\mathrm{He}^{b} 67 \%+\mathrm{H}_{2} 33 \%$ & 5,000 & 34.5 & & 1285 & & & & & & 21 \\
\hline & 871 & $\mathrm{He}^{b} 67 \%+\mathrm{H}_{2} 33 \%$ & 5.000 & 34.5 & & 1479 & & & & & & 21 \\
\hline & 871 & $\mathrm{He}^{b} 67 \%+\mathrm{H}_{2} 33 \%$ & 5.000 & 34.5 & & 1505 & & & & & & 21 \\
\hline & 871 & $\mathrm{He}^{b}+$ oil contumination & 5,000 & 34.5 & & 804 & & & & & & 21 \\
\hline & 871 & $\mathrm{He}^{b}+$ oil contamination & 5,000 & 34.5 & & 978 & & & & & & 21 \\
\hline \multirow[t]{21}{*}{ Hastelloy $x$} & 649 & $\mathrm{He}^{d}$ & 44,000 & 303.4 & $2.5 \times 10^{-5}$ & 194 & 75 & & & 40 & & 15 \\
\hline & 760 & $\mathrm{He}^{d}$ & 25,000 & 172.4 & $5.0 \times 10^{-5}$ & 37.5 & 84 & 79 & & 10 & & 15 \\
\hline & 760 & $\mathrm{He}^{d}$ & 25,000 & 172.4 & $5.0 \times 10^{-5}$ & 37.5 & 86 & 83 & & 12 & & 15 \\
\hline & 871 & $\mathrm{He}^{d}$ & 10,000 & 69 & $5.0 \times 10^{-6}$ & 201.5 & 79 & 84 & & 70 & & is \\
\hline & 871 & $\mathrm{He}^{d}$ & 10,000 & 69 & $3.7 \times 10^{-6}$ & 314.0 & 93 & 88 & & 110 & & 15 \\
\hline & 871 & $\mathrm{He}^{d}$ & 10.000 & 69 & $8.3 \times 10^{-6}$ & 171.0 & 75 & 90 & & 55 & & 15 \\
\hline & 800 & $\mathrm{He}^{e}$ & 4,400 & 31 & 0.00 & & & & & 6000 & & 2 \\
\hline & 900 & $\mathrm{He}^{e}$ & 1900 & 13 & & 2760 & 5.02 & & & & & 2 \\
\hline & 900 & $\mathrm{He}^{\mathrm{e}}$ & 1,900 & 13 & & 3170 & 4.85 & & & & & 2 \\
\hline & 800 & Air & 4.400 & 30.3 & $5.0 \times 10^{-7}$ & & & & & & & cited in ref. 2 \\
\hline & 900 & $\mathrm{Ajr}$ & 1900 & 13 & $8.0 \times 10^{-7}$ & & & & & & & cited in ref. 2 \\
\hline & 750 & $\mathrm{He}^{\mathrm{f}}$ & 14,200 & 98 & $1.58 \times 10^{-5}$ & & & & & & & 5 \\
\hline & 750 & $\mathrm{He}^{\mathrm{f}}$ & 13,000 & 90 & $6.31 \times 10^{-6}$ & & & & & & & 5 \\
\hline & 750 & $\overline{\mathrm{He}}^{j}$ & 9.900 & 68 & $1.74 \times 10^{-6}$ & & & & & & & 5 \\
\hline & 750 & $\mathrm{He}^{f}$ & 9,900 & 68 & $7.59 \times 10^{-7}$ & & & & & & & 5 \\
\hline & 750 & $\mathrm{He}^{f}$ & 9,000 & 62 & $1.29 \times 10^{\circ}$ & & & & & & & 5 \\
\hline & 750 & $\mathrm{He}^{f}$ & 9,000 & 62 & $8.13 \times 10^{-7}$ & & & & & & & 5 \\
\hline & 750 & $\mathrm{He}^{f}$ & 8,000 & 55 & $4.26 \times 10^{-7}$ & & & & & & & 5 \\
\hline & 750 & $\mathrm{He}^{f}$ & 8,000 & 55 & $2.00 \times 10^{-7}$ & & & & & & & 5 \\
\hline & 750 & Air & 8,700 & 60 & $1.29 \times 10^{-6}$ & & & & & & & 5 \\
\hline & 750 & Air & 7,800 & 54 & $3.63 \times 10^{-2}$ & & & & & & & 5 \\
\hline
\end{tabular}

No data given for $0.5 \%$ and $1.0 \%$ strain.

$b_{0.2}$ mole $\% \mathrm{H}_{2}, 0.1$ mole $\% \mathrm{~N}_{2}$, "no other detectable impurities."

${ }^{c} 380 \mu \mathrm{atm} \mathrm{H} \mathrm{H}_{2}, 36 \mu \mathrm{atm} \mathrm{CH}_{4}, 24 \mu \mathrm{atm} \mathrm{CO}, 8 \mu \mathrm{atm} \mathrm{H}_{3} \mathrm{O},<10^{-16}$ atm $\mathrm{O}_{2}$

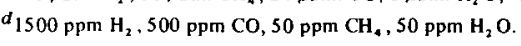

e $500 \mu \mathrm{atm} \mathrm{\textrm {H } _ { 2 }}, 50 \mu \mathrm{atm} \mathrm{CO}, 50 \mu \mathrm{atm} \mathrm{CH}_{4}, 0.5-3 \mu \mathrm{atm} \mathrm{\textrm {H } _ { 2 }} \mathrm{O}$ at $70 \mathrm{~atm}$ pressure.

$500 \mu \mathrm{atm} \mathrm{H}_{2}, 50 \mu \mathrm{atm} \mathrm{CO}, 1.5 \mu \mathrm{atm} \mathrm{H}_{2} \mathrm{O}, 50 \mu \mathrm{atm} \mathrm{CH}_{a} \leq \leq 11 \mu \mathrm{atm} \mathrm{N}_{2}$ at $1.8 \mathrm{~atm}$ pressure 
Table 7. Summary of creep data for other alloys

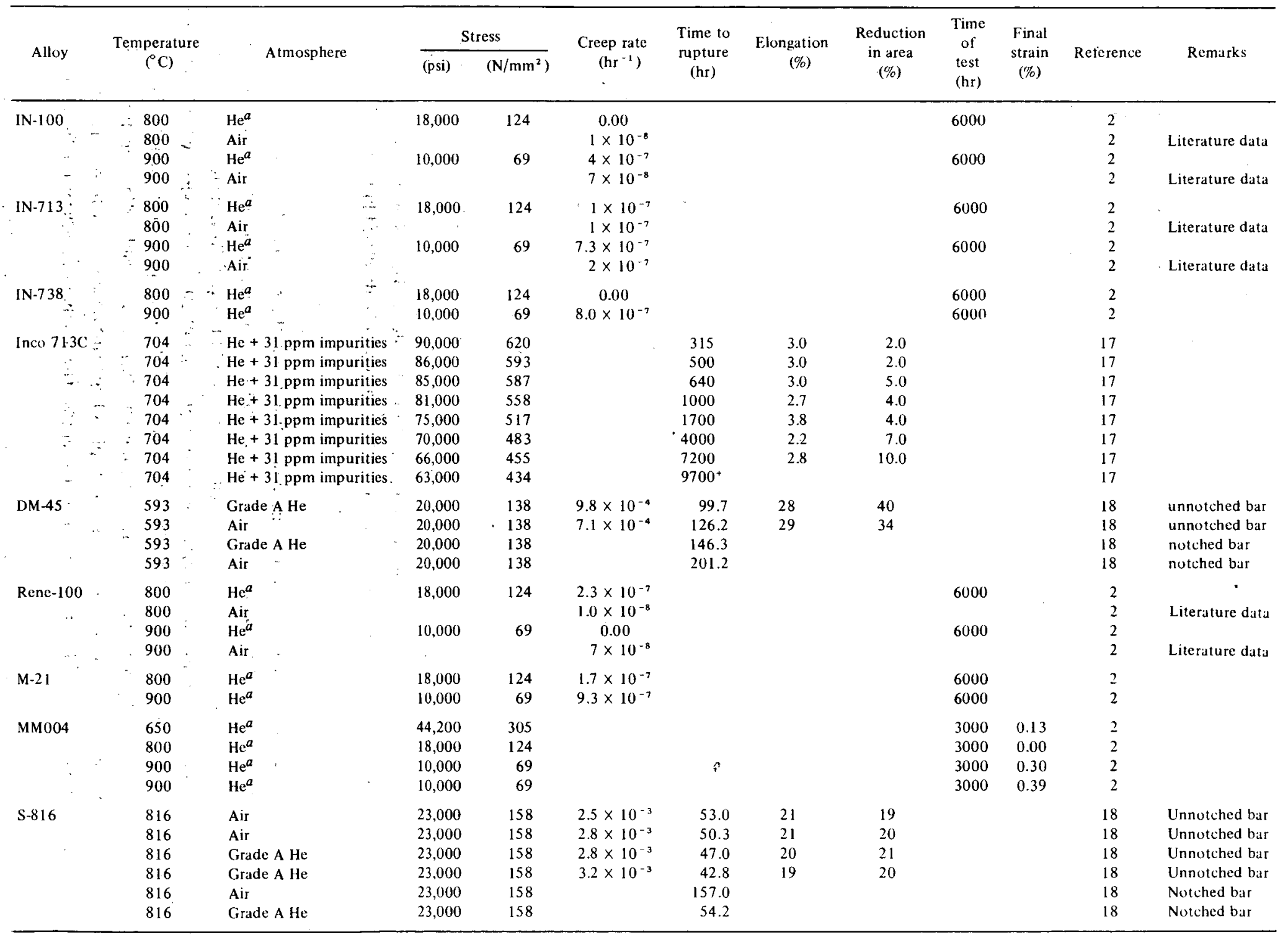

${ }^{a} 500 \mu \mathrm{atm} \mathrm{H}_{2}, 50 \mu \mathrm{atm} C \mathrm{O} .50 \mu \mathrm{atm} \mathrm{CH}_{4}, 0.5-3 \mu \mathrm{atm} \mathrm{H} \mathrm{H}_{2} \mathrm{O}$ at $70 \mathrm{~atm}$ pressure. 
Table 8. Summary of comparisons between helium and air creep data

\begin{tabular}{|c|c|c|c|c|c|c|}
\hline \multirow[t]{2}{*}{ Alloy } & \multirow{2}{*}{$\begin{array}{c}\text { Temperature } \\
\left({ }^{\circ} \mathrm{C}\right)\end{array}$} & \multirow{2}{*}{$\begin{array}{l}\text { Creep rate: } \\
\frac{\dot{R}_{c}(\mathrm{He})}{\mathrm{R}_{\mathrm{c}}(\mathrm{Air})}\end{array}$} & \multirow{2}{*}{$\begin{array}{l}\text { Time to } \\
\text { rupture: } \\
\frac{t_{r}(\mathrm{He})}{t_{r}(\mathrm{Air})}\end{array}$} & \multirow{2}{*}{ 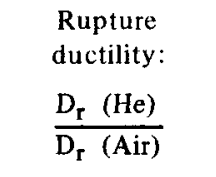 } & \multicolumn{2}{|c|}{$\begin{array}{c}\text { Concentration } \\
(\%)\end{array}$} \\
\hline & & & & & $\mathrm{Ti}$ & $\mathrm{Al}$ \\
\hline Incoloy 800 & 650 & $>1$ & $<1$ & $\begin{array}{l}>1(\text { pure } \mathrm{He}) \\
<1(\text { impure } \mathrm{He})\end{array}$ & 0.4 & 0.4 \\
\hline Inconel X & 816 & $\sim 1$ & $<1$ & $>1$ & 2.5 & 0.9 \\
\hline Inconel 617 & $\begin{array}{l}800 \\
850 \\
900\end{array}$ & $\begin{array}{l}<1 \\
<1 \\
<1\end{array}$ & & $>1$ & & 1.0 \\
\hline Inconel 625 & $\begin{array}{l}750 \\
850\end{array}$ & & $\begin{array}{l}>1 \\
<1\end{array}$ & $\begin{array}{l}>1 \\
>1\end{array}$ & 0.2 & 0.2 \\
\hline Hastelloy C & 871 & & $<1$ & & & \\
\hline Hastelloy X & $\begin{array}{l}704 \\
750 \\
760 \\
800\end{array}$ & $\begin{array}{r}\sim 1 \\
1 \\
<1 \\
<1\end{array}$ & $\begin{array}{c}<1(\curvearrowright 1) \\
1\end{array}$ & $\begin{array}{l}>1 \\
<1\end{array}$ & & \\
\hline IN-100 & $\begin{array}{l}800 \\
900\end{array}$ & $\begin{array}{l}<1^{a} \\
>1\end{array}$ & & & 4.7 & 5.5 \\
\hline IN-713 & $\begin{array}{l}800 \\
900\end{array}$ & $\begin{array}{r}1 \\
>1\end{array}$ & & & 0.85 & 6.0 \\
\hline Inco $713 \mathrm{C}$ & 704 & & $<1$ & & 0.7 & 6.0 \\
\hline DM-45 & 593 & $>1$ & $<1$ & $\sim 1$ & & \\
\hline Rene 100 & $\begin{array}{l}800 \\
900\end{array}$ & $\begin{array}{l}>1 \\
<1^{a}\end{array}$ & & & 4.1 & 5.4 \\
\hline
\end{tabular}

${ }^{a}$ Based on minimum creep rate in helium of 0.00 .

Any discussion of mechanisms will be complicated by the variables mentioned above. In addition to these complications, there are a number of effects that occur during treatment in the various atmospheres which can either enhance or detract from the properties of the alloys. These effects include cracking, oxidation of alloying constituents, and carburization. Each of these will be discussed in turn.

\section{Cracking}

Work was conducted by Stegman, Shahinian, and Achter ${ }^{30}$ on the effects of oxygen on the creeprupture properties of nickel. These workers found that at $600^{\circ} \mathrm{C}$ the minimum creep rate decreased with increased oxygen pressure to about $10^{-4}$ torr oxygen; above this pressure no further increase was observed. Similarly, the rupture life decreased with increasing pressure up to about $10^{-4}$ torr oxygen, where it leveled off. Similar results were observed at $510^{\circ} \mathrm{C}$, although scatter in the data prevented the assignment of a precise critical pressure. Oxygen pressure was also shown to have considerable effect on the depth of surface cracks: as the oxygen pressure increases, the depth of the surface cracks $/$ increases. The density of internal cracks was not appreciably altered by pressure changes. The number of cricks was a function of the temperature.

These results are explained in terms of an adsorption model,,$^{30-31}$ and a mathematical expression was derived to justify the model. This model is based on a study of creep-rupture properties in air and in 
vacuum. The results of the istudy indicated that at low stresses. and high temperature nickel is stronger in air, but that at high stresses and low temperatures it is stronger in vacuum. A mechanism was proposed involving two competing processes: oxidation strengthens the metal, while adsorption of oxygen lowers the surface energy relative to that.in vacuum and reduces the work required to propagate a crack; the process which controls in any given.instance is determined by stress and temperature. An adsorption model would predict that crack propagation rates should increase with gas pressure until some critical pressure is reached at which the surface is saturated at the same rate as it is generated; further increases in pressure should have no additional effect. This prediction is verified by experiment. ${ }^{30}$ Furthermore, calculations based on this model predict a critical pressure of $7 \times 10^{-5}$ torr, which is in good agreement with the experimental value of $10^{-4}$ torr. Unfortunately, this work was not extended to pressures above 10 torr.

Other investigators have reported confusing effects of treatment of alloys in air vs helium. Shahinian ${ }^{19}$ reported that specimens of iron-based superalloys tested between 593 and $816^{\circ} \mathrm{C}$ in air contained a few cracks near the fracture, while specimens tested in vacuum and in Grade A helium showed many intercrystalline cracks along the gage length. In addition, a "grain" structure developed at the surface. On the other hand, for Incoloy 800 , Bates et al. ${ }^{10}$ report that surface-crack nucleation was easier in air (at $650^{\circ} \mathrm{C}$ ) than it was in helium. The primary effect of this was to cause earlier onset of tertiary creep in air tests. However, the strain during.tertiary creep and the duration of tertiary creep was greater in air than in helium. The result of all these effects is that even though the time to rupture was longer in helium, the elongation was less. Similar results were noted for Inconel 625 at $650^{\circ} \mathrm{C}$. These latter results have prompted concern that, at least for HTR helium, surface-crack initiation will be suppressed but crack propagation rate will be increased, which may seriously limit ductility in tertiary creep. Support for this hypothesis is found in the work of Shahinian, ${ }^{19}$ who found that for alloys of relatively low ductility, such as S-816 and Inconel $\mathrm{X}$, the presence of a notch greatly increased the susceptibility of the materials to the influence of the environment. This fact is explained by a proposed mechanism in which cracks that form are oxidized at the tip, which relieves the stress concentration, slowing the progress of the crack. This would explain the longer time to rupture in air as compared to helium.

Several investigators have suggested that there may be an optimum oxygen partial pressure that will produce the highest creep and rupture strengths. ${ }^{3,19,21,30}$ Experimental work on stainless steel has pointed further to this possibility, and the concept certainly merits further work.

Surface cracking from any cause should have little effect on creep properties, because it is a surface effect and creep is in general controlled by bulk effects..$^{2,30}$ Since the growth of surface cracks is affected by the environment, no severe effects should be expected until the final stage of creep failure, when cracks begin to join up and grow faster. At this point oxygen has access to inner cracks. Thus, surface cracks should have a relatively small effect on creep, as compared to fatigue. Effects other than cracking should operate to control creep. These effects, which control the bulk properties of the alloys, include internal oxidation, alloy depletion, and carburization-decarburization.

\section{Oxidation of alloy constituents}

Most of the studies discussed in this report have been conducted, using fairly low concentrations of $\mathrm{H}_{2} \mathrm{O}, \mathrm{CO}, \mathrm{CO}_{2}, \mathrm{~N}_{2}, \mathrm{O}_{2}, \mathrm{H}_{2}$, and $\mathrm{CH}_{4}-$ usually less than 500 ppm. Thermodynamically, however, the partial pressures of these impurities do not influence the possibility of a particular chemical reaction. These reactions are controlled by the oxidation potentials $\mathrm{H}_{2} / \mathrm{H}_{2} \mathrm{O}$ and $\mathrm{CO} / \mathrm{CO}_{2}$. Total gas pressure only controls the availability of reacting species and thus the kinetics of the reactions. The relative amounts of the species determine the oxidation potential or the carburization potential of the atmosphere. It has been shown in Fig. 1 that under the atmospheres discussed in this report most of the alloying constituents of superalloys, 
with the exception of iron, nickel, molybdenum, and tungsten, are oxidizable. ${ }^{3}$ Oxidation can therefore influence the effect of treatment in helium on the bulk properties.

Chromium forms a surface oxide primarily because of its availability to the surface and its relatively high diffusion rate: Removal of, chromium produces a tendency for carbides tci dissolve. Aluminum and titanium form both surface oxides and internal oxides, depending on their concentration and on the time and temperature of the test. Aluminum is a primary constituent of the $\gamma^{\prime}$ phase used for precipitation hardening, and titanium is substitutionally soluble in this phase. Removal of these two elements can therefore affect the mechanical properties considerably. Manganese and silicon usually migrate to the grain boundaries, thus their oxidation could result in grain boundary embrittlement. Molybdenum and tungsten are added as strengtheners, so their removal could lower the mechanical properties. The formation of a continuous adherent oxide layer at the surface is very important. As mentioned previously, a nonuniform oxide layer at the surface promotes internal oxidation and/or evaporation of certain alloying constituents.

Returning to Table 8 , it was noted earlier that no clear-cut relationship exists between creep rate in helium and creep rate in air. However, it may be possible to generalize and explain the difference between the two rates. Comparing the results in Table 8 with Table 1, it is seen that with the exception of Incoloy 800 those alloys which show a creep rate lower in helium than in air are also low in aluminum. This suggests that the presence of aluminum promotes higher creep rates. The exact reason for this is not known at this time, but the following are possible explanations:

1. Oxidation of aluminum from the surface decreases the amount of $\gamma^{\prime}$ precipitate.

2. Oxidation of aluminum destroys its effectiveness as a solid solution hardener at the surface.

3. Internal oxidation of aluminum near the surface does not strengthen the surface layer, so the effective cross section is decreased, which in turn increases the effective creep rate.

4. Oxidation of aluminum at grain boundaries acts as a crack initiator. Growth cf these cracks under stress serves to increase the creep rate.

In those works which cited catastrophic effects on creep bahavior, no such effects were observed after treatment in helium containing reactive impurities. While it is true that significant changes occurred in creep behavior because of the helium treatment, the changes for the most part were less than $50 \%$. Even though the effects of helium on creep properties are not large, they are real. Thus, it is imperative that the use of superalloys in any system involving helium and using critical design parameters must be preceded by extensive creep studies in the proposed atmosphere.

\section{Carburization}

The presence of $\mathrm{CO}$ in the test atmosphere means that deposition of carbon irito the surface of the alloy is possible by means of the Boudouard reaction:

$$
2 \mathrm{CO} \leftrightarrows \mathrm{CO}_{2}+\mathrm{C}
$$

At low temperature the reaction shifts to the right, although the reaction rate is low. However, nickel and iron catalyze the deposition of carbon ${ }^{3,17}$ and can result in carburization.

From the discussions above on surface reactions for the individual alloys, it 'can be seen that carburization is by far the most common reaction. Conditions under which decarburization has been observed have already been discussed: In some works where decarburization is discussed, it is not always clear whether the data suggest a mere loss of carbides from the chromium depletion layer or actual carbon loss from the sample. In at least one instance, careful reading reveals that the former is the case. ${ }^{29}$ Bates et al. ${ }^{10}$ have 
observed that intergranular oxidation was almost invariably associated with carburization. Simultaneous intergranular oxidation and carburization did not produce any detrimental effects on creep resistance or any recognizable tendency for earlier creep cracking.

\section{Fatigue}

It is apparent from Table 2 that very little work has been done on the fatigue properties of superalloys in helium. Wall, Hengstenberg, and Gayley ${ }^{18}$ have studied Inconel X, Inco $713 \mathrm{C}$, and Inco 700 in Grade A helium; but no comparable air data are given. Their data are summarized in Table 9. However, since air data are not available, it is not possible to assess the effects of the helium environment on these alloys.

The effect of variations in the temperature and pressure of different atmospheres on nickel was studied by Achter, Danek, and Smith. ${ }^{32}$ Atmospheres of vacuum, nitrogen, oxygen, argon, and helium were studied. At $816^{\circ} \mathrm{C}$, a plot of the $\log$ of cycles to failure (N) vs the $\log$ of air pressure showed an initial decrease in $\log \mathrm{N}$ followed by a leveling off at about $10^{-5}$ torr. The curve drops off again at about $10^{-3}$ torr, and near atmospheric pressure an increase is noted. The pressure at which leveling off begins is believed to be the point of surface saturation with oxygen. Calculations based on an adsorption model indicate that saturation should occur at $10^{-4}$ torr, so agreement with experiment is fair. The decrease at $10^{-3}$ torr is considered to be due to diffusion of oxygen along grain boundaries ahead of the crack, and the upturn in the curve at $10^{2}$ torr is believed to be due to oxidation strengthening. The fatigue life in low-pressure oxygen is longer than that in high-pressure oxygen. Metallographic analysis suggests that at $300^{\circ} \mathrm{C}$ there is an increase in the rate of crack nucleation with increasing gas pressure, while at $816^{\circ} \mathrm{C}$ the rate of crack propagation increases with gas pressure but not the rate of nucleation.

Data obtained in other environments are summarized in Table $10 .^{32}$ The fact that fatigue lives in inert gases are comparable to those in oxygen is taken as evidence that the level of reactive impurities in the inert gases is sufficient to saturate the crack surfaces.

The only other work available on fatigue is that of Kondo, Kikuyama, and Shindo, ${ }^{12}$ who studied Incoloy 800 in moist $\left(400 \mu \mathrm{atm} \mathrm{H}_{2} \mathrm{O}\right.$ ) helium. This work indicated that fatigue was accompanied by an apparent acceleration in creep deformation and associated cracking. At a frequency of $100 \mathrm{cpm}$, crack growth rate at $700^{\circ} \mathrm{C}$ was independent of environment. At $30 \mathrm{cpm}$, some effect of notch sensitivity was observed. The crack growth rate was higher in helium at high stress intensity factors, while at low stress

Table 9. Fatigue strengths and notch factors ${ }^{a}$

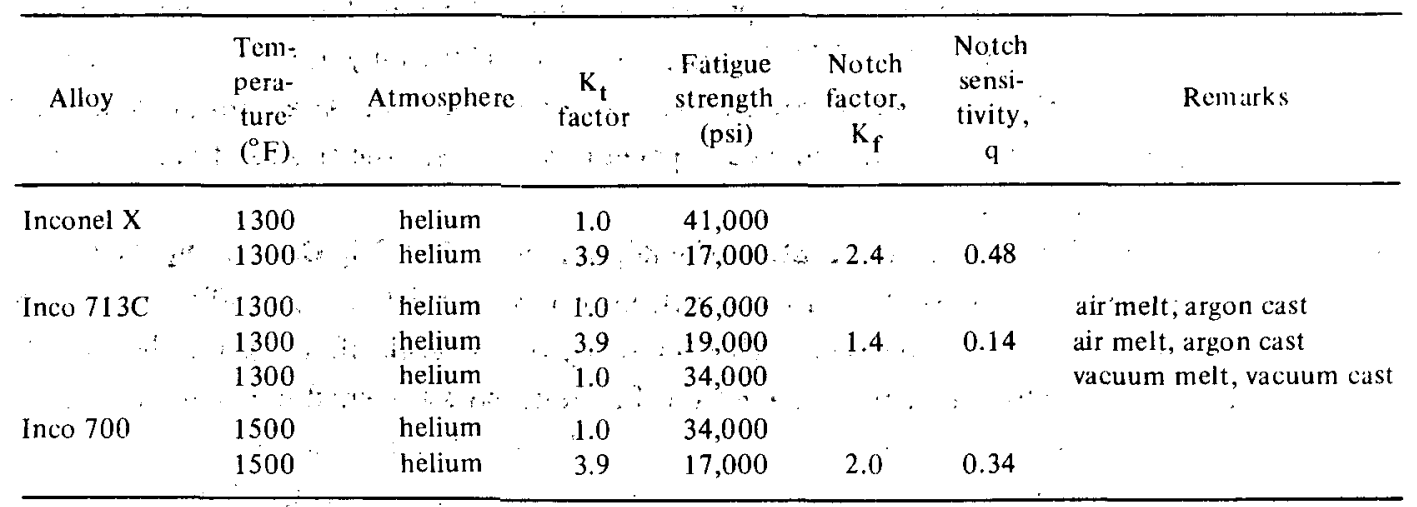

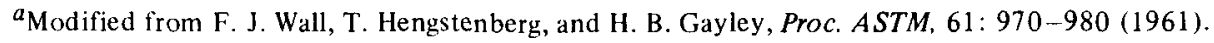


Table 10. Fatigue life of nickel in various environments (hr) ${ }^{a, t}$

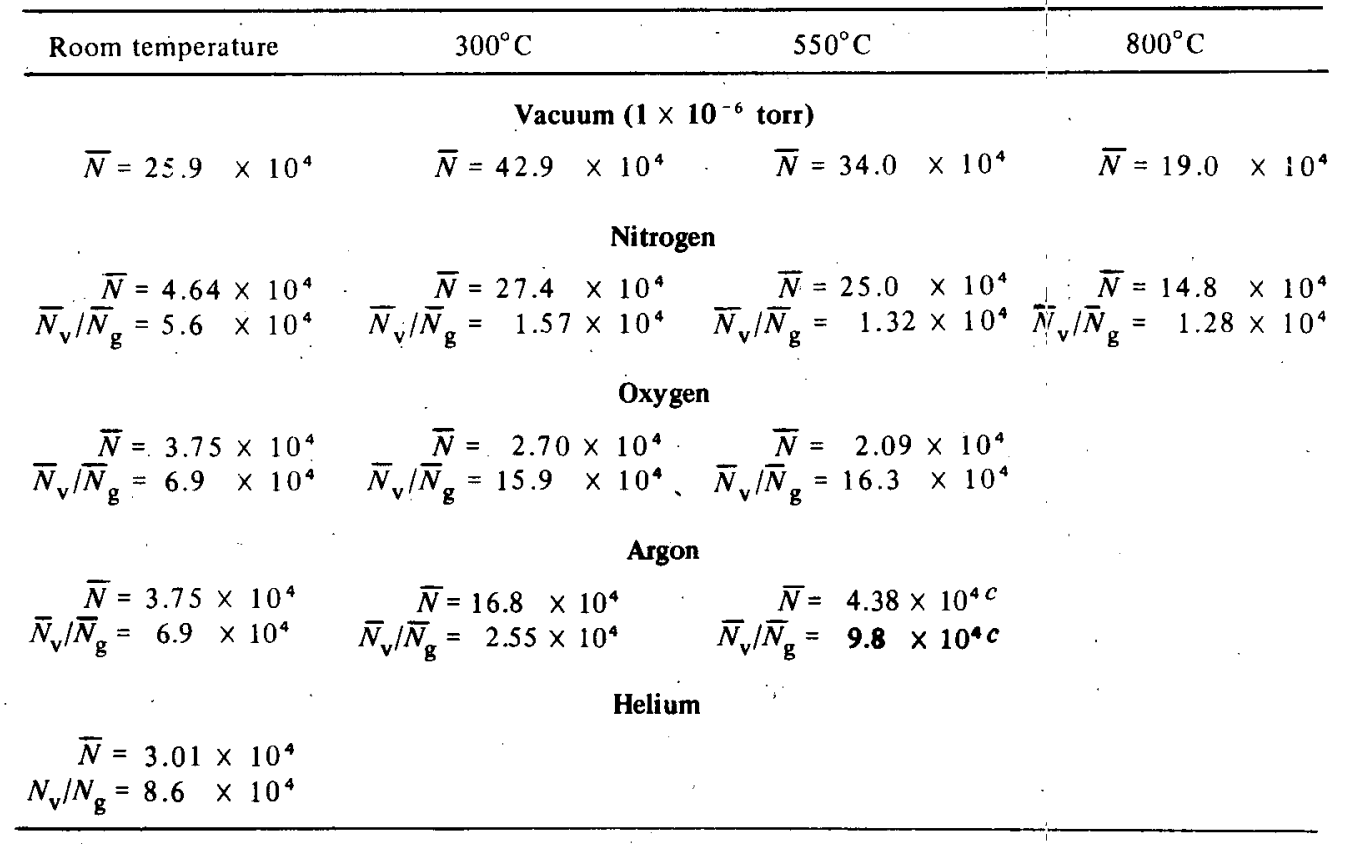

${ }^{a}$ Modified from M. R. Achter, G. J. Danek, Jr., and H. H. Smith, Trans. Metall. Soc. AIME, 227: $1296-1301$ (1963).

${ }^{b}$ Plastic strain $=0.170 \%$.

${ }^{c}$ No cooling water to flanges.

intensity factors it was higher in air. Metallographic analysis showed that cracks in helium were intergranular while cracks in air were transgranular.

In view of this great lack of data on the fatigue properties of superalloys in helium, it is obvious that much work is needed. Since reaction in helium promotes the nucleation of crack;, one would expect a more severe effect on fatigue, which is a surface property. This is suggested by the vork of Kondo, Kikuyama, and Shindo ${ }^{12}$ at the lower frequency; but considering the number of variables operable much work remains to be done.

\section{Tensile Properties}

Data on the effects of helium on the tensile properties of superalloys are limited. Tables 11 and 12 give the data available on several superalloys. ${ }^{2,11}$ However, data are given only for tests of material in the as-received condition in both cases, and no comparable tests were run in air. As a result, it is impossible to determine the exact result of the use of helium as compared to air. Synergistic effects of heat treatment and environment are possible factors.

Studies on Nimonic 75 were made by Knutsen, Condé, and Piene ${ }^{29}$ in $\mathrm{CO}_{2}, \mathrm{CO}, \mathrm{H}_{2}, \mathrm{~N}_{2}, \mathrm{H}_{2} \mathrm{O}$, and $\mathrm{CH}_{4}$ used in various mixtures, pressures $(0.01$ torr to $1 \mathrm{~atm})$, and temperatures $\left(750\right.$ to $\left.1050^{\circ} \mathrm{C}\right)$. Unfortunately, this work was not accompanied by comparable air data; so again synergistic effects cannot be identified. In 0.1 torr $\mathrm{CO}_{2}$ a decrease in ultimate tensile strength was found which was related to depletion of chromium carbides. After depletion was complete, the tensile strength decreased more slowly with time; this decrease was attributed to the effect of surface and grain boundary oxidation. The total change in the ultimate tensile strength was about $27 \%$ at $1050^{\circ} \mathrm{C}$. 
Table 11. Room temperature mechanical properties after exposure to impure helium $^{b}$

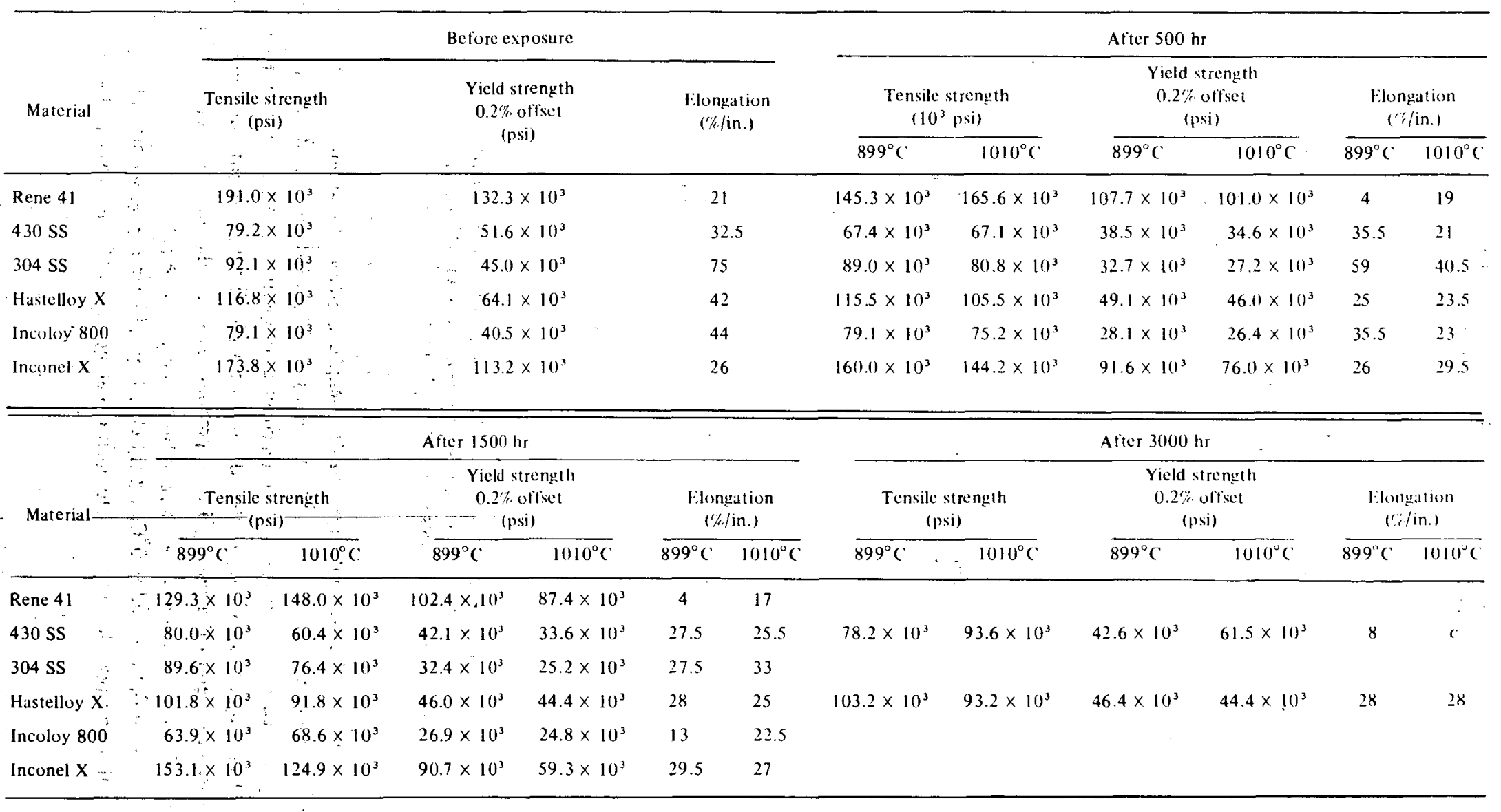

${ }^{a} 3000 \mathrm{ppm}$ each, $\mathrm{CO}$ and $\cdot \mathrm{H}_{2}$

${ }^{b}$ From J. W. Wunderlich and N. F. Baker, Exposure of HTGR Candidate Core Plate and Thermal Insulation Materials to Impure Helium at $16.50^{\circ} \mathrm{F}$ to $1850^{\circ} \mathrm{F}$ for $3000 \mathrm{Hours}$. GAMD-7377, General Atomic Company, San Diego, Calif. (December 29, 1966).

cBroke out of gage. 
Table 12. Summary of tensile property data after $3000 \mathrm{hr}$ in controlled-impurity helium ${ }^{a}$

\begin{tabular}{|c|c|c|c|c|}
\hline \multirow{2}{*}{ Alloy } & \multirow{2}{*}{$\begin{array}{l}\text { Temp } \\
\left({ }^{\circ} \mathrm{C}\right)\end{array}$} & \multicolumn{3}{|c|}{$\begin{array}{l}\text { Room-temperature property chang } \\
\text { relative to as-received material }(\%)\end{array}$} \\
\hline & & $\begin{array}{l}\text { Tensile } \\
\text { strength }\end{array}$ & $\begin{array}{l}\text { Yieid } \\
\text { strength }\end{array}$ & Elongation \\
\hline \multirow[t]{4}{*}{ IN 100} & 650 & +2.8 & +8.5 & -19.2 \\
\hline & 800 & -8.7 & -6.4 & -38.5 \\
\hline & 800 & -9.8 & -8.4 & -38.5 \\
\hline & 900 & -12.1 & -32.0 & - -42.3 \\
\hline \multirow[t]{3}{*}{ Rene 100} & 650 & -1.4 & +6.9 & -29.2 \\
\hline & 800 & -12.4 & -4.5 & -37.5 \\
\hline & 900 & -2.4 & -17.4 & -16.7 \\
\hline \multirow[t]{3}{*}{ IN 738} & 650 & +2.7 & -14.0 & -0.1 \\
\hline & 800 & -9.3 & +0.4 & -41.8 \\
\hline & 900 & -19.7 & -8.0 & -69.7 \\
\hline \multirow[t]{4}{*}{ M 21} & 650 & -0.2 & +10.1 & -4.1 \\
\hline & 800 & +4.5 & -6.8 & -30.1 \\
\hline & 800 & -4.1 & -7.3 & -56.2 \\
\hline & 900 & -9.8 & -23.8 & -61.6 \\
\hline \multirow[t]{4}{*}{ IN 713} & 650 & +1.8 & +12.2 & -29.6 \\
\hline & 800 & -10.9 & -12.2 & -29.6 \\
\hline & 800 & -13.7 & -10.8 & -63.0 \\
\hline & 900 & -4.2 & -20.0 & +40.7 \\
\hline \multirow[t]{3}{*}{ MM 004} & 650 & +6.6 & +14.2 & 00 \\
\hline & 800 & -5.2 & -2.9 & -83 \\
\hline & 900 & -17.2 & -12.1 & -483 \\
\hline \multirow[t]{4}{*}{ Inconel 617} & 650 & +28.9 & +65.0 & -421 \\
\hline & 800 & +12.0 & +12.8 & -407 \\
\hline & 800 & +11.5 & +14.0 & -40.3 \\
\hline & 900 & -38.0 & -2.0 & $-88: 6$ \\
\hline \multirow[t]{4}{*}{ Hastelloy $X$} & 650 & +44.4 & -51.8 & $-66: 9$ \\
\hline & 800 & +13.8 & -4.1 & -69.1 \\
\hline & 800 & +4.7 & -10.1 & $-78 ! 6$ \\
\hline & 900 & & & \\
\hline
\end{tabular}

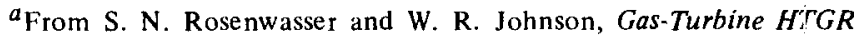
Materials Screening Test Program Interim Results, GA-A 13931, General Atomic Company, San Diego, Calif. (June 30, 1976).

Under 0.1 torr $\mathrm{CO}$ at $750^{\circ} \mathrm{C}$, the ultimate tensile strength decreased by about 12 to $15 \%$, the yield strength decreased by about $65 \%$, and the elongation increased. When $\mathrm{CH}_{4}$ was /used, the resulting carburizing conditions produced various effects on the mechanical properties. These effects are believed to be associated with (1) the interaction of carbon with the surface oxide film, (2) cartiurization and diffusion of carbon into the specimens, and (3) accumulation of precipitates along the grain boundaries. The strength initially decreases by $\sim 7 \%$, then increases $\sim 13 \%$, and finally slowly decreases.

With $\mathrm{CO}+\mathrm{H}_{2}(1: 1)$ at 0.2 torr and $900^{\circ} \mathrm{C}$, a slight change ( $\left.15 \%\right)$ in the tensile strength occurred after $300 \mathrm{hr}$ exposure, although a $60 \%$ decrease in yield occurred along with a $20 \%$ increase in elongation.

With a mixture of $\mathrm{N}_{2}+\mathrm{CO}+\mathrm{H}_{2}+\mathrm{H}_{2} \mathrm{O}+\mathrm{CH}_{4}$ (1:3:3:0.5:0.5), the results were very similar to those obtained in the $\mathrm{CO}_{2}$ tests. A $27 \%$ decrease in ultimate tensile strength occurred after $200 \mathrm{hr}$ at $900^{\circ} \mathrm{C}$ and 0.3 torr pressure, although the yield strength decreased by $72 \%$ and and the elongation increased $45 \%$. 
While none of these changes were catastrophic, they were significant, and they suggest the need for more definitive work.

\section{Impact Properties}

Only one reference was made to impact properties, in the study by Rosenwasser and Johnson. ${ }^{2}$ Their results are summarized in Table 13. In all cases a decrease in impact strength was observed after $3000 \mathrm{hr}$ at $800^{\circ} \mathrm{C}$. These decreases are thought to be previously associated with thermal aging.

\section{SUMMARY}

Changes in the corrosion resistance and mechanical properties of superalloys in helium as compared to air appear to be primarily due to the fact that in helium a discontinuous oxide scale is produced, while in air the scale is usually continuous. The consequences of this situation can vary, depending on the alloy and the composition of the gas atmosphere. If the atmosphere is reducing, decarburization can occur, with subsequent changes in mechanical properties. If the atmosphere is oxidizing, internal oxidation and intergranular oxidation can occur; a continuous coating serves to minimize internal oxidation. However, if the atmosphere is too pure, chromium and manganese evaporation occurs.

While it appears that some oxygen is desirable in the environment, there are ample data which suggest that a minimum level in the mechanical properties exists at a select oxygen concentration. This critical concentration may be variable from alloy to alloy; its effect is to produce a minimum in rupture time. The problem for a given alloy is to accurately determine the rupture life as a function of oxygen concentration and then to operate a system sufficiently above or below the critical concentration to obtain the rupture life desired.

In general, treatment in helium produces significant but not catastrophic changes in the structure and properties of these alloys. However, as seen in Tables $4-7$, few of the creep tests were carried out for longer than six months, so that long-term application has not been addressed adequately.

The time to rupture is generally longer in air than in helium, and in most cases rupture ductility is greater in helium than in air. The effects of helium on creep rate are mixed. In some cases creep rate in air is higher than in helium and in other cases the opposite is true. Evidence exists which suggests that high creep

Table 13. Summary of impact property data after 3000 hr at $800^{\circ} \mathrm{C}$ in controlled-impurity helium ${ }^{a}$

\begin{tabular}{|c|c|c|}
\hline & Alloy & $\begin{array}{l}\text { Change in room temperature } \\
\text { impact strength relative to } \\
\text { as-received material (\%) }\end{array}$ \\
\hline $\begin{array}{l}\cdots \div-\cdots \\
\cdots \cdots+\ddots \cdots\end{array}$ & $\begin{array}{l}\text { IN } 100 \\
\text { M } 21 \\
\text { IN } 713 \\
\text { Inconel } 61.7 \\
\text { Hastelloy X }\end{array}$ & \begin{tabular}{rrr}
$\therefore$ & -37.5 \\
$\because$ & -42.0 \\
7 & $\therefore$ & $<-46.0$ \\
\hdashline & -91.3
\end{tabular} \\
\hline
\end{tabular}

${ }^{a}$ From S. N. Rosenwasser and W. R. Johnson, Gas-Turbine HTGR Materials Screening Test Program Interim Results, GA-A13931, General Atomic Company, San Diego, Calif. (June 30,1976 ). 
rates in helium are associated with high aluminum content of the alloy. Crack propagation rates may also increase in helium.

Fatigue crack propagation is promoted by increased oxygen pressure, until the oxygen content is sufficient to saturate the new crack surfaces. Very low oxygen pressures are required to increase fatigue life. Metallographic eviaence suggests that cracks in helium are intergranular while those in air are transgranular. The reason for this is not known at this time, but it may have something to do with preferential diffusion of oxygen down grain boundaries ahead of the crack.

\section{SUGGESTIONS FOR FURTHER WORK}

A review such as this often asks more questions than it answers, and this revjew is no exception. This situation is due in part to the variety of alloys, atmospheres, and experimental techniques. It is also due to the fact that comparable tests were not run in both helium and air, so that in many cases there is no basis for comparison. Among the questions that require answers and further work are the following:

1. What are the exact effects of crack nucleation and propagation in alloys as compared to the effects in pure nickel?

2. What changes in mechanical properties are due to the effects of heat treatment and which are due to the effects of environment?

3. What are the effects of the individual alloying additions ( $\mathrm{Ti}, \mathrm{Al}, \mathrm{Nb}, \mathrm{Cr}, \mathrm{Co}, \mathrm{Ta}, \mathrm{Mo}, \mathrm{W}$, and $\mathrm{C})$ in various environments on corrosion resistance and mechanical properties?

4. What are the critical oxygen concentrations for the different alloys and how do they compare with those for pure nickel?

5. In fatigue, the effects of variable frequency should be studied.

6. What effects do grain boundary impurities have on intergranular oxidation, that is, is vacuum-melted material to be preferred over air-melted material?

7. The effects of surface treatments such as calorizing should be studied in more detail in order to reduce internal oxidation.

8. The effects of environment on crack nucleation and propagation should be studied in more detail under more controlled conditions.

9. Why are cracks in fatigue intergranular in helium and transgranular in air?

10. An alloy development program directed toward alloys for helium environments should be initiated.

These suggestions are probably by no means complete, and it is anticipated that the reader will no doubt produce more.

\section{ACKNOWLEDGMENTS}

The author would like to acknowledge the assistance of Helen F. Kuhns of the Central Research Library for assistance in computer retrieval of references, H. E. McCoy and A. C. Schafftiauser for technical review of the manuscript, and Susan Derieux for typing the original manuscript.

This task was supported by ERDA Division of Nuclear Research and Applications, Office of Space Applications. 


\section{APPENDIX}

Summary of Atmospheres Used by Various References

\begin{tabular}{|c|c|}
\hline Reference & Atmosphere \\
\hline 1 & $\mathrm{He}-\mathrm{Xe}$ \\
\hline 2 & $\mathrm{He}+0.5-3 \mu \mathrm{atm} \mathrm{H}_{2} \mathrm{O}, 500 \mu \mathrm{atm} \mathrm{H}_{2}, 50 \mu \mathrm{atm} \mathrm{CO}, 50 \mu \mathrm{atm} \mathrm{CH}_{4}$ \\
\hline 3 & $\mathrm{He}+2.5 \mathrm{ppm} \mathrm{H}_{2} \mathrm{O}, 12.5 \mathrm{ppm} \mathrm{H}_{2}, 12.5 \mathrm{ppm} \mathrm{CO}$ \\
\hline 4 & Air; nominally pure $\mathrm{He}$; $\mathrm{He}$ containing $1000 \mathrm{ppm} \mathrm{H}_{2}, 1000 \mathrm{ppm} \mathrm{CO}, 100 \mathrm{ppm}_{2} \mathrm{O}$ \\
\hline 5 & $\mathrm{He}+500 \mu \mathrm{atm} \mathrm{H}_{2}, 50 \mu \mathrm{atm} \mathrm{CO}, 1.5 \mu \mathrm{atm} \mathrm{H}_{2} \mathrm{O}$ \\
\hline 6 & $\mathrm{He}+200 \mu \mathrm{atm} \mathrm{H}_{2}+20 \mu \mathrm{atm} \mathrm{CH}_{4} ; \mathrm{He}+200 \mu \mathrm{atm} \mathrm{H}_{2}+20 \mu \mathrm{atm} \mathrm{CH}_{4}+10 \mu \mathrm{atm} \mathrm{CO}$ \\
\hline 7 & $\mathrm{He}+30 \mathrm{ppm} \mathrm{H}_{2}, 30 \mathrm{ppm} \mathrm{CO}, 5 \mathrm{ppm} \mathrm{H}_{2} \mathrm{O}$ \\
\hline 8 & 15-torr $\mathrm{H}_{2} \mathrm{O}$ in Grade $\mathrm{A}$ helium \\
\hline 9 & $\mathrm{He}+500 \mu \mathrm{atm} \mathrm{H}_{2}, 50 \mu \mathrm{atm} \mathrm{CO}, 50 \mu \mathrm{atm} \mathrm{CH}_{4} 1.5 \mu \mathrm{atm} \mathrm{H}_{2} \mathrm{O}$ \\
\hline 10 & $\mathrm{He}+50-100 \mathrm{ppm} \mathrm{H}_{2}, 25-50 \mathrm{ppm} \mathrm{CO}, 3-8 \mathrm{ppm} \mathrm{CH}_{4} 0.5-3 \mathrm{ppm} \mathrm{H}_{2} \mathrm{O}, \leq 11 \mathrm{ppm} \mathrm{N}_{2}$ \\
\hline 11 & Purified $\mathrm{He} ; \mathrm{He}+300 \mathrm{ppm} \mathrm{CO}+\mathrm{H}_{2} ; \mathrm{He}+3000 \mathrm{ppm} \mathrm{CO}+\mathrm{H}_{2}$ \\
\hline 12 & 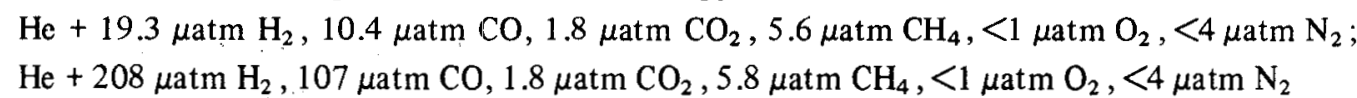 \\
\hline 13 & Variable $\mathrm{CO}, \mathrm{H}_{2} \mathrm{O}$, and $\mathrm{CH}_{4}$ at varying pressure \\
\hline 14 & Helium with $12-15$ ppm $\mathrm{H}_{2}, 10-12 \mathrm{ppm} \mathrm{CO}, 1-2 \mathrm{ppm} \mathrm{CH}_{4}, 1-2 \mathrm{ppm} \mathrm{H}_{2} \mathrm{O}$ \\
\hline 15 & $\begin{array}{l}\mathrm{He}+5.3 \mathrm{ppm} \mathrm{H}_{2} \mathrm{O}, 5.0 \mathrm{ppm} \mathrm{H}, 10 \mathrm{ppm} \mathrm{CO}, 5.0 \mathrm{ppm} \mathrm{CO}_{2}, 5.0 \mathrm{ppm} \mathrm{CH}_{4}, 5.0 \mathrm{ppm} \mathrm{N}_{2} ; \mathrm{He}+ \\
5.0 \mathrm{ppm} \mathrm{H}_{2} \mathrm{O}, 218 \mathrm{ppm} \mathrm{H}_{2}, 113 \mathrm{ppm} \mathrm{CO}, 1.96 \mathrm{ppm} \mathrm{CO}_{2}, 6.15 \mathrm{ppm} \mathrm{CH}_{4},<1.0 \mathrm{ppm} \mathrm{N}_{2}\end{array}$ \\
\hline 16 & $\mathrm{He}+1500 \mu \mathrm{atm} \mathrm{H}_{2}, 500 \mu \mathrm{atm} \mathrm{CO}, 50 \mu \mathrm{atm} \mathrm{CH}_{4}, 50 \mu \mathrm{atm} \mathrm{H}_{2} \mathrm{O}$ \\
\hline 17 & Grade A helium gettered to $<5 \mathrm{ppm} \mathrm{H}_{2} \mathrm{O}, 1 \mathrm{ppm} \mathrm{O}_{2}$ plus controlled impurities $\mathrm{CO}+\mathrm{CO}_{2}$ \\
\hline 18 & Grade A helium, $17-89$ ppm impurities $\left(\mathrm{H}_{2}, \mathrm{~N}_{2}, \mathrm{O}_{2}, \mathrm{CO}_{2}\right)$ \\
\hline 19 & Grade A helium \\
\hline 20 & Grade A helium; $18 \mu \mathrm{m}-1$ atm $0 ; 23-100$ torr $\mathrm{CO}_{2} ; 28$ torr $\mathrm{H}_{2} \mathrm{O}$ \\
\hline 21 & Helium with varying impurity levels $0-1010 \mathrm{ppm} \mathrm{O}_{2}, 0.7-2.6 \mathrm{ppm} \mathrm{H}_{2} \mathrm{O}$ \\
\hline 22 & $\mathrm{He}+0.2$ mole $\% \mathrm{H}_{2}, 0.1$ mole $\% \mathrm{~N}_{2}$ \\
\hline 23 & Helium; Nitrogen (analyses not given) \\
\hline 24 & He with $<1 \mathrm{ppm}$ by volume $\mathrm{O}_{2}+\mathrm{N}_{2}+\mathrm{H}_{2}+\mathrm{CO}+\mathrm{H}_{2} \mathrm{O}+\mathrm{CH}_{4}$ \\
\hline 25 & He with $<1_{\text {s }}$ pm impurities \\
\hline 26 & He with $\sim 1.5$ ppm each $\mathrm{CO}, \mathrm{H}_{2}, \mathrm{H}_{2} \mathrm{O}, \ldots \ldots$ \\
\hline 27 & $\mathrm{He}+380 \mu \mathrm{atm} \mathrm{H}, 36 \mu \mathrm{atm} \mathrm{CH} 24 \mu \mathrm{atm} \mathrm{CO}, 8 \mu \mathrm{atm} \mathrm{H} \mathrm{H}_{2},<10^{-16} \mu \mathrm{atm} \mathrm{O}_{2}$ \\
\hline 28 & Air; low-pressure oxygen; $\mathrm{CH}_{4}$ \\
\hline 29 & Variable partial pressures of $\mathrm{CO}_{2}, \mathrm{H}_{2} \mathrm{O}, \mathrm{CO}, \mathrm{CH}_{4} \mathrm{~N}_{2}(0.01$ torr to $1 \mathrm{~atm})$ \\
\hline 30 & Variable oxygen pressure $\left(10^{-7}\right.$ to $10^{1}$ torr oxygen $)$. \\
\hline 31 & Air and vacuum \\
\hline 32 & Vacuum, $\mathrm{N}_{2}, \mathrm{O}_{2}, \mathrm{Ar}, \mathrm{He}$ (all passed through drying columns) \\
\hline 33 & Ultrapure He; low-pressure oxygen . . . . \\
\hline 34 & Air, low-pressure oxygen, Grade A helium \\
\hline 35 & Grade A helium passed through $\mathrm{Zr}$ getter bed ( $\sim 1 \mathrm{ppm}$ impurities) \\
\hline 36 & $\mathrm{He}+380 \mu \mathrm{atm} \mathrm{H}_{2}, 36 \mu \mathrm{atm} \mathrm{CH}_{4}, 24 \mu \mathrm{atm} \mathrm{CO}, 8 \mu \mathrm{atm} \mathrm{H}_{2} \mathrm{O},<10^{-16} \mu \mathrm{atm} \mathrm{O}_{2}$ \\
\hline 37 & $\mathrm{He}+380 \mu \mathrm{atm} \mathrm{H}_{2}, 36 \mu \mathrm{atm} \mathrm{CH}, 24 \mu \mathrm{atm} \mathrm{CO}, 8 \mu \mathrm{atm} \mathrm{H}_{2} \mathrm{O},<10^{-16} \mu \mathrm{atm} \mathrm{\textrm {O } _ { 2 }}$ \\
\hline
\end{tabular}




\section{REFERENCES}

1. Airesearch Manufacturing Company of Arizona, Brayton Isotope Power System Configuration Control Document (CCD), Document No. 75-311274B (March 15, 1976). (Limited distribution document, available from Aircsearch).

2. S. N. Rosenwasser and W. R. Johnson, Gas-Turbine HTGR Materials Screening Test Program Interim Results, GA-A13931, General Atomic Company, San Diego, Calif. (June 30, 1976).

3. J. Board, J. Brit. Nucl. Energy Soc. 9: 101-112 (1970).

4. D. S. Wood, M. Farrow, and W. T. Burke, "A Preliminary Study of the Effect of Helium Environment on the Creep and Rupture Behavior of Type 316 Stainless Steel and Incoloy 800", pp. 213-28 in Effects of Environment on Material Properties in Nuclear Systems: Proceeding of the International Conference on Corrosion, Institution of Civil Engineers, London, 1971.

5. R. H. Cook, D. F. Lupton, and H. G. A. Bates, Behavior of Materials for Advanced High Temperature Reactors, DP Report 970, Dragon Project, Winfrith, England (January 1976).

6. F. N. Mazandarany, Effects of Elevated Temperature Exposure to a Simulated HTGR Primary Coolant Environment on Several Unstressed Austenitic Alloys, GA-A 13462, General Atomic Company, San Diego, Calif. (August 15, 1975).

7. R. A. U. Huddle; "The Influence of HTR Helium on the Behavior of Metals in High Temperature Reactors," pp. 203-12 in Effects of Environment on Material Properties in Nuclear Systems: Proceedings of the International Conference on Corrosion, Institution of Civil Engineers, London, 1971.

8. T. T. Claudson and R. E. Westerman, An Evaluation of the Corrosion Resistance of Several High Temperature Alloys for Nuclear Applications, BNWL-155, Battelle Northwest Laboratories, Richland, Wash. (November 1965).

9. H. G. A. Bates, K. B $\phi y e$, and F. Wade, Status Report on the Dragon Project Metals Programme at CIIR Oslo on Materials for Advanced Applications, DPTN/744, Dragon Project, Winfrith, England (December 10, 1975).

10. H. G. A. Bates, W. Betteridge, R. H. Cook, L. W. Graham, and D. F. Lupton, The Influence of Impure Helium on Properties of Some Austenitic Steels, DP Report 934, Dragon Project, Winfrith, England (May 1975).

11. J. W. Wunderlich and N. E. Baker, Exposure of HTGR Candidate Core Plate and Thermal Insulation Materials to Impure Helium at $1650^{\circ} \mathrm{F}$ to $1850^{\circ} \mathrm{F}$ for 3000 Hours, GAjMD-7377, General Atomic Company, San Diego, Calif. (December 29, 1966).

12. T. Kondo, T. Kikuyama, and M. Shindo, "Corrosion and Fatigue of Superalloys in Simulated HTGR Helium Environment at Very High Temperatures," pp. 163-78 in Corrosion Problems in Energy Conversion and Generation, ed. by Craig S. Tedmon, Corrosion Division, The Electrochemical Society, Princeton, N.J., 1974.

13. J. E. Antill, K. A. Peakall, and J. R. Warburton, "The Transfer of Carbon from an Inert Gas Containing Carbon Monoxide or Methane to Iron and Nickel Bare Alloys," p'p. 187-194 in Effects of Environment on Material Properties in Nuclear Systems: Proceedings of the International Conference on Corrosion, Institution of Civil Engineers, London, 1971.

14. J. Dixmier, D. Leclercq, P. Olivier, L. Vincent, and H. Willermoz, "Investigation of the Behavior of 35\% Nickel Alloys in the Presence of Helium Coolant Impurities," pp. 363-77 in Gas-Cooled Reactor with Emphasis on Advanced Systems: Vol I, IAEA-SM-200/61; International Atomic Energy Agency, Vienna (1976). 
15. M. Sakakibara, I. Banno, and S. Sekino, Tetsu to Hagane, 60(12): 1655-60 (1974); ORNLtr-4223, Oak Ridge (1976).

16. R. J. Wolwowicz, Creep-Rupture Properties of Incoloy 800H, 21/4 Cr $-1 \mathrm{Mo}$, and Hastelloy $\mathrm{X}$ Alloys in Simulated HTGR Environment - Interim Report, GA-A 13876, General Atomic Company, San Diego, Calif. (June 1976).

17. J. C. Bokros and H. E. Shoemaker, Reactor Materials Compatibility with Impurities in Helium, GA-1508 General Atomic Company, San Diego Calif. (January 12, 1971).

18. F. J. Wall, T. Hengstenberg, and H. B. Gayley, Proc. ASTM 61: 970-80 (1961).

19. P. Shahinian, Trans. ASM 49: 862-82 (1957).

20. L. A. Charlot and R. E. Westerman, High Temperature Corrosion of Candidate ATR Structural Materials, BNWL-100, Battelle Northwest Laboratories, Richland, Wash. (September 1965).

21. Y. Hosoi and S. Abe, Metall. Trans. 6A: 1171-78 (1975).

22. O. C. Shepard and W. Schalliol ASTM Spec. Tech. Pub. 108: 34-8 (1950).

23. T. T. Claudson and H. J. Pessl, Evaluation of Iron-and Nickel-base Alloys for Medium and High Temperature Reactor Applications: Part II, BNWL-154, Battelle Northwest Laboratories, Richland, Wash. (November 1965).

24. L. A. Charlot, L. D. Blackburn, and R. E. Westerman, in Quarterly Progress Report April, May, June, 1967, Reactor Fuels and Materials Development Programs, BNWL-473, Battelle Northwest Laboratories, Richland, Wash. (September 1967).

25. L. A. Charlot, R. A. Thiede, and R. E. Westerman, Corrosion of Superalloys and Refractory Metals in High Temperature Flowing Helium, BNWL-SA-1137, Battelle Northwest Laboratories, Richland, Wash. (March 1967).

26. R. A. Thiede and R. E. Westerman, in Quarterly Progress Report: Irradiation Effects on Reactor Structural Materials August, September, October, 1966, BNWL-883, Bat telle Northwest Laboratories, Richland, Wash. (November 15, 1966).

27. A. Lystrup in Mechanical Properties Test Data for Structural Materials Quarterly Progress Report for Period Ending July 31, 1976, compiled by M. R. Hill, ORNL-5200, Oak Ridge (September 1976).

28. L. A. Charlot and R. E. Westerman, in Quarterly Progress Report: Irradiation Effects on Reactor Structural Materials August, September, October, 1964, HW-84517, General Electric Corp., Hanford, Wash. (November 16, 1964).

29. A. B. Knutsen, J. F. G. Condé, and K. Piene, Br. Corros. J. 4: 94-104 (1969).

30. R. L. Stegman, P. Shahinian, and M. R. Achter, Trans. Metall. Soc. AIME 245: 1759-63 (1969).

31. M. R. Achter and H. W. Fox, Trans. Metall. Soc. AIME 215: 295-96, (1959).

32. M. R. Achter, G. J..Danek, Jr., and H. H. Smith, Trans. Metal. Soc. AIME 227: 1296-1301 (1963).

33. L. A. Charlot and R. E. Westerman, in Quarterly Progress Report: Irradiation Effects on Reactor Structural Materials November, December 1965, January 1966, BNWL-CC-510, Battelle Northwest Laboratories, Richland, Wash. (February 1966).

34. D. A. Jones and R. E. Westerman, in Quarterly Progress Report: Irradiation Effects on Reactor Structural Materials February, March, April 1963, HW-77281, General Electric Corp., Hanford, Wash. (May 15, 1963).

35. L. A. Charlot and R. E. Westerman in Quarterly Progress Report: Irradiation Effects on Reactor Structural Materials August, September, October 1965, BNWL-CC-355, Battelle Northwest Laboratories, Richland, Wash. (1965).

36. A. Lystrup, in Mechanical Properties Test Data for Structural Materials Quarterly Progress Report for Period Ending October 31, 1976, compiled by M. R. Hill, ORNL-5237, Oak Ridge (December 1976). 
37. C. R. Brinkman, P. L. Rittenhouse, W. R. Corwin, J. P. Strizak, A. Lystrup, and J, R. DiStefano, Application of Hastelloy X in Gas-Cooled Reactor Systems, ORNL/TM-5405 (October.1976). 
1-2. Central Research Library

3. Document Reference Section

4-8. Laboratory Records Department

9. Laboratory Records, ORNL RC

10. ORNL Patent Office

11. D. N. Braski

12. C. R. Brinkman

13. J. A. Carter

14. J. E. Cunningham

15. F. L. Culler

16. J. H. DeVan

17. J. R. DiStefano

18. R. G. Donnelly

19. J. I. Federer

20. G. M. Goodwin

21. J. P. Hammond

22. D. E. Harasyn

23. R. L. Heestand

24. R. F. Hibbs

25-27. M. R. Hill

28. J. A. Horak
29. H. Inouye

30. J. R. Keiser

31. E. Lamb

32. C. T. Liu

33. W. R. Martin (Y-12)

34. H. Postma

35-36. A. C. Schaffhauser

37. G. M. Slaughter

38. J. O. Stiegler

39. V. J. Tennery

40. D. B. Trauger

41. J. R. Weir, Jr.

42. C. L. White

43. R. O. Williams

44. R. W. Balluffi (consultant)

45. P. M. Brister (consultant)

46. W. R. Hibbard, Jr. (consultant)

47. Hayne Palmour III (consultant)

48. N. E. Promisel (consultant)

49. D. F. Stein (consultant)

\section{EXTERNAL DISTRIBUTION}

50. AiResearch Manufacturing Company of Arizona, 402 South 36th Street, P.O. Box 5217, Phoenix, AZ 85010 J. E. McCormick

51. Battelle Memorial Institute, 505 King Avenue, Columbus, OH 43201 C. Alexander

52. Fairchild Space and Electronics Company, Germantown, MD 20767

$$
\text { A. Shock }
$$

53. General Electric Company, Nuclear Programs, P.O. Box 8661, Philadelphia, PA 19101 E. W. Williams

54. Gulf Energy and Environmental Systems, P.O. Box 608, San Diego, CA 92112

N. Elsner

55. Kirtland Air Force Base, NM 87117

Directorate of Nuclear Safety

56-57. Los Alamos Scientific Laboratory, P.O. Box 1663, Los Alamos, NM 87545

S. E. Bronisz

S. Hecker

58-59. Monsanto Research Corporation, P.O. Box 32, Miamisburg, OH 45342

E. W. Johnson

W. D. Klapp 
60. NASA Lewis Research Center, 21000 Brookpark Rd, Cleveland, OH $4 \$ 135$

61. North American Phillips Co., Briarcliff Manor, NY 10510

Otmar H. Boser

62. Sunstrand Energy Systems, 4747 Harrison Avenue, Rockford, IL 61101

E. Kreuger

63-64. Teledyne Energy Systems, 110 West Timonium Road, Timonium, ML 21093

W. J. Barnett

W. Osmeyer

65-75. ERDA Division of Nuclear Research and Application, Washington, DC 20545

W. D. Kenney

A. P. Litman

J. J. Lombardo

A. L. Mowery

G. A. Newby

B. J. Rock

C. O. Tarr

N. R. Thielke

E. J. Wahlquist

76. ERDA Oak Ridge Operations Office, P.O. Box E, Oak Ridge, TN 37830

Research and Technical Support Division

77-320. ERDA Technical Information Center, Office of Information Services.|P.O. Box 62, Oak Ridge, TN 37830

For distribution as shown in TID-4500 Distribution Category UC-25 (Materials) 